\title{
PRAVNA REGULACIJA POLOŽAJA LOBISTA U EUROPI
}

\author{
Prof. dr. sc. Sanja Baric** \\ Ana Acinger, mag. iur.**
}

\author{
UDK 328.184(4) \\ https://doi.org/10.30925/zpfsr.39.3.6 \\ Ur.: 23. srpnja 2018. \\ Pr.: 17. rujna 2018. \\ Prethodno priopćenje
}

\begin{abstract}
Sažetak
Pravnu regulaciju lobiranja u Europi autorice prikazuju kroz prizmu Europske unije, ali i međunarodnih organizacija koje djeluju na području Europe te pojedinih država na njezinom teritoriju. Prikazano je i postojanje, odnosno nepostojanje, odgovarajućih propisa, registra transparentnosti $i$ etičkog kodeksa u državama članicama Europske unije, s posebnim naglaskom na onim državama članicama u kojima postoji zakonski propis koji regulira lobiranje te prednosti i nedostatci takvih zakonskih akata.
\end{abstract}

Ključne riječi: Europska unija, lobiranje, pravo na slanje predstavki i pritužbi, zakonska regulacija lobiranja, registar transparentnosti.

\section{1. $U V O D$}

Kada je riječ o pitanju pravne regulacije lobiranja, uočljiva su dva pristupa. ${ }^{1}$ Prvi, prema kojem je lobiranje potpuna negacija demokracije (čiji zagovornici smatraju pritom da bi se demokratska volja trebala utjelovljavati jedino kroz demokratski izabrano predstavničko tijelo ili institut poput referenduma koji ima kakvu-takvu narodnu legitimaciju). Drugi, koji lobiranje definira upravo kao demokratsko pravo (u većini država zagarantirano ustavom kao najvišim pravnim aktom), a koje se očituje u pravu na slanje predstavki i pritužbi tijelima javne vlasti te nastojanju utjecanja na kreatore javnih politika, shvaćene kao pojedince ili grupe. Gledano kroz prizmu liberalne demokracije, postoje četiri načela, jednakog značaja i primjenjivosti za sve države, kojima se zakonodavac treba voditi pri regulaciji lobiranja. Ona su osobito važna u kontekstu Europe kao kontinenta, a potom i kao pravne tvorevine EU-a, budući da se radi o području s velikim kulturološkim, političkim i drugim različitostima. Ta su načela: odgovornost (accountability), transparentnost (transparency), otvorenost

* Dr. sc. Sanja Barić, redovita profesorica Sveučilišta u Rijeci, Pravnog fakulteta; sbaric@pravri. hr.

** Ana Acinger, mag. iur., odvjetnička vježbenica; ana.acinger@gmail.com.

1 Bitonti, Alberto, Harris, Phil, Lobbying in Europe, Public Affairs and the Lobbying in 28 EU Countries, Palgrave Macmillan, United Kingdom, 2017., str. 17. 
(openess) te pravednost (fairness). ${ }^{2}$ Ona korespondiraju s općepoznatim načelima dobre vladavine u EU. ${ }^{3}$ Odgovornost znači dužnost donositelja javnih odluka da opravdavaju svoje postupke. Minimalna razina odgovornosti podrazumijeva barem dužnost objašnjavanja kako su izabrani na određene pozicije, a visoka razina odgovornosti odnosi se na opravdavanje svakog poteza i svake javno donesene odluke. Kroz transparentnost se omogućuje javno motrenje tijela vlasti, što nesumnjivo doprinosi većoj odgovornosti. Otvorenost bi podrazumijevala uspostavljanje kanala komunikacije tijela javne vlasti sa svim dionicima uključeni, u donošenje pojedine odluke i, posljedično, doprinosi i transparentnosti i odgovornosti. I posljednje načelo, pravednost, zapravo je jamstvo da se pristup i mogućnost sudjelovanja dionika u procesima donošenja odluka odvijaju u pravednim (fair) uvjetima. Imajući na umu rečena načela te shvaćajući lobiranje kao „konzistentan i direktan pokušaj utjecaja na proces donošenja odluka“" ${ }^{4}$ ujedno uočavajući da je lobiranje djelatnost koja je u stalnom rastu po broju uključenih subjekata, financijskih sredstava te utjecaju „,izlobiranih“ odluka, postaje očita važnost odgovarajuće pravne regulacije ove djelatnosti. U ovom se radu tematizira položaj lobista na razini Europske unije kao cjeline (1), a potom i na razini pojedinih država članica EU-a (2). Naposljetku se razmatra i širi kontekst međunarodnih organizacija na području Europe: Vijeće Europe (3.1.) i OECD (3.2.). Druge jurisdikcije obrađuju se na drugim mjestima. ${ }^{5}$

\section{ANALIZA LOBIRANJA U EUROPSKOJ UNIJI}

Europska unija, odnosno Bruxelles kao njezino sjedište, meka je raznih interesnih skupina, koje, na ovaj ili onaj način, nastoje utjecati na donošenje ili blokiranje neke odluke pri institucijama EU-a. Implikacije dotičnog čina mogu posredno obuhvatiti znatan broj dionika, no njegovi neposredni učinci zasigurno su i veći. Primjerice, ako se donese propis o poskupljenju nameta na određeni proizvod, a koji se izravno odnosi na proizvođače, učinke toga propisa osjetit će i prerađivači te osnovne sirovine, ali i dobavljači, te, u konačnici, sami potrošači. S druge strane, neki konkurentski proizvod može time profitirati i opet će učinci biti dalekosežniji, no što bi se na prvi pogled moglo zamijetiti. Razvidan je, dakle, učinak prelijevanja s jedno na drugo tržište i brojnost osoba koje će u konačnici osjetiti posljedice. Imajući u vidu tako pojednostavljen, ali važan primjer iz svakodnevice,

2 Ibid., str. 26-27.

3 Commission of the European Communities, European Governance, A White Paper, Brussels, 25.7.2001., dostupno na: https:/ec.europa.eu/europeaid/sites/devco/files/communicationwhite-paper-governance-com2001428-20010725_en.pdf, posjećeno 05.01.2018.

4 Franklin B. et al., Key concepts in public relations, London: SAGE Los Angeles, 2009, str. 126., dostupno na: https://books.google.hr/books?hl=hr\&lr=\&id= ND1RVZzu8QsC\&oi=fnd\&pg=PT1\&dq=Franklin + B. + et + al., + Key + concepts + in + public + relations, + London: + SAGE + Los + Angeles,$+2009 \&$ ots $=$ HHullIQUqd\&sig=VP2he6aOs-p3r bo8vYiyiBZG_I\&redir_esc=y\#v=onepage\&q=consistent\&f=false, posjećeno 05. 01. 2018.

5 Članak „Pravna regulacija položaja lobista u Europi“ nadovezuje se na „Pravnu regulaciju položaja lobista u Sjedinjenim Američkim Državama“, a pravna regulacija lobiranja u Republici Hrvatskoj bit će obrađena kroz zasebnu cjelinu pa će ovdje naglasak biti na ostale države članice EU i institucije EU te na VE i OECD. 
moguće je uočiti postojanje različitih, nerijetko oprečnih interesa koji će neminovno u određenom trenutku pokušati utjecati na institucije radi mogućnosti ostvarenja svojih probitaka. Promatrajući prijavljene troškove potrošene na lobiranje, pri samom su vrhu kompanije koje najviše troše ExxonMobil i Shell, s prijavljenih gotovo pet milijuna eura u 2014. godini. ${ }^{6}$ Visokotehnološku industriju predstavljaju Microsoft, Google, Siemens i Huawei, a na listi su se našli i Dow Chemicals, GE i Deutsche Bank. Vidljivo je da na lobiranje najviše troše energetska, tehnološka i financijska industrija, a slijede ih kemijska, farmaceutska i poljoprivredna industrija. Godine 2016. na lobiranje u Bruxellesu potrošeno je rekordnih 1.7 milijardi eura. ${ }^{7}$ Lobiranje u Bruxellesu moglo bi se promatrati i kao „borbu“ između nastojanja očuvanja statusa quo i napora civilnog društva za promjenama, a ishod je najčešće negdje u sredini. ${ }^{8}$

\subsection{Etape razvoja lobiranja kao profesije u kontekstu promjena unutar Europske unije}

Prema Danielu Guéguenu, ${ }^{9}$ jednom od najpoznatijih i najistaknutijih lobista u Europskoj uniji, razlikuju se četiri etape razvoja lobiranja u EU-a koje odgovaraju pojedinoj fazi europske integracije. To su: vrijeme stvaranja (tzv. fuzijsko lobiranje) od 1957. do 1970.; vrijeme oseke (tzv. diplomatsko lobiranje) od 1971. do 1987.; jedinstveno tržište (tzv. strateško lobiranje) od 1988. do 2005. te „Europa 30 nacija“ (tzv. transverzalno lobiranje) od 2006. do danas. Obilježje je prve etape da je to vrijeme nastanka Europske ekonomske zajednice (1958.), na temelju Rimskih ugovora iz 1957. godine, kojima je, uz spomenutu, osnovana i Europska zajednica za atomsku energiju - Euratom. To je razdoblje ,intenzivne legislativne i regulatorne aktivnosti obilježeno stvaranjem, tzv. Zajedničke poljoprivredne politike $(C A P)$, provedbom preferencija Zajednice i osnivanjem organizacija Zajedničkog tržišta (za žito, meso, šećer itd. $)^{\text {“ }}{ }^{10}$ Najistaknutije ličnosti ove etape su Henri Cayre ${ }^{11}$ te André Herlistka; ${ }^{12}$ koji se smatraju ,simbolima fuzijskog lobiranja“. U sljedećoj etapi, u takozvanom vremenu oseke, dolazi do zastoja u aktivnostima EEZ-a te se pojavljuje nova vrsta

6 Bitonti, A., Harris, Ph., Lobbying ..., op. cit., str. 39.

7 Big East-West skew in record EU lobbying bonanza, Politico, dostupno na: https://www. politico.eu/article/transparency-register-analysis-lobbying-east-west-skew-european-union/, posjećeno 1.3.2018.

8 Bitonti, A., Harris, Ph., Lobbying ..., op. cit., str. 38-41.

9 Guéguen, Daniel, Europsko lobiranje, Miropictures i Novum, Zagreb, 2007., str. 15-17.

10 Ibid., str. 15.

11 Henry Cayre, predvodnik europskog sektora šećerne repe i utemeljitelj Europskog informacijskog servisa te pionir modernog lobiranja, "tipični poljoprivredni govornik s talentom da iskoristi sve prednosti političkog svijeta“", Chalmin, Philippe, The Making of a Sugar Giant: Tate and Lyle, 1859-1989., str. 465., dostupno na: https://books.google.hr/ books?id=bOPogF $8 v 9-\mathrm{kC} \& \mathrm{pg}=\mathrm{PA} 465 \& \mathrm{lpg}=\mathrm{PA} 465 \& \mathrm{dq}=$ henri + cayre + who + was + he $\&$ sourc $\mathrm{e}=\mathrm{bl} \&$ ots $=\mathrm{kHiOh} 7 \mathrm{QRvG} \&$ sig=RDdtcps6n-c86mDU7HPhgYTBsG4\&hl=hr\&sa=X\&ved=0a hUKEwiSj_jFm-XZAhVDICwKHcVHAEoQ6AEIJjAA\# $\mathrm{v}=$ onepage \&q=henri\%20cayre $\% 20$ who\%20was\%20he\&f=false, posjećeno 28.02.2018.

12 André Herlistka, generalni tajnik Udruženja profesionalnih poljoprivrednih organizacija i vrstan poznavatelj zajedničke poljoprivredne politike Unije. 
lobista: lobisti-diplomati. Većina organizacija toga doba nalazi se u Parizu, dok su GATT u Ženevi i FAO u Rimu, pa se komunikacija lobista s visokopozicioniranim dužnosnicima tih organizacija odvija rijetko, ali učinkovito, a karakterizira je elegantan diplomatski manirizam. U sljedećoj etapi - fazi jedinstvenog tržišta - uočava se važnost Jacquesa Delorsa koji je „drastično reformirao institucije (Jedinstveni europski akt iz 1987.) osiguravajući povratak glasovanju kvalificiranom većinom, isključivo pravo predlaganja (i pisanja nacrta) zakonskih dokumenata Komisiji i krajnji rok 1. siječnja 1993. za ostvarenje Jedinstvenog europskog tržišta. "“3 U ovom razdoblju ${ }^{14}$ dolazi do nestanka diplomatskog lobiranja te do preseljenja lobista iz Pariza u Bruxelles, kao i nastanka nekih lobističkih tehnika koje su se zadržale do današnjih dana. Primjerice, „više ne dolazi u obzir raditi samo s Komisijom, Parlament je postao esencijalnim elementom, grupe eksperata se umnožavaju, civilno društvo (sindikati, nevladine organizacije) investiraju u Bruxelles, a akreditiranim medijima raste važnost pa postaju vrlo važnim sredstvom u lobiranju. ${ }^{\text {"15 }}$ Pojavljuje se i transverzalno lobiranje, tj. „sposobnost da se odnosi izgrađuju između nižih i viših razina, od proizvođača do potrošača" ${ }^{16}$ a sektorsko lobiranje pomalo nestaje te se lobista počinje smatrati partnerom, a ne više opozicijom.

\subsection{Akteri lobiranja u $E U$}

Akteri lobiranja vrlo su različiti subjekti. Oni uključuju razne skupine, „od multinacionalnih kompanija i trgovačkih udruženja, konzultantskih kuća, poslodavačkih i sindikalnih saveza preko nevladinih organizacija, poput udruga za zaštitu okoliša ili prava potrošača, do predstavnika nacionalnih ministarstava, lokalnih ili regionalnih vlasti i javnih agencija. " ${ }^{\text {"17 }}$ Nadalje, lobisti ne moraju dolaziti samo iz država članica, već, primjerice, iz drugih zemalja kao što su Kina, Japan ili SAD, a „kao lobistički akteri nerijetko djeluju i sami službenici i odjeli Europske komisije, Parlamenta, Vijeća i drugih tijela i agencija EU.“18 Uzevši navedeno u obzir, razvidno je na koliko se različitih razina može odvijati lobiranje u Europskoj uniji i o koliko dinamičnom procesu s koliko sudionika zapravo je riječ. Istodobno, nije riječ o jednostranoj koristi lobista. Naime i institucije EU-a dobivaju povratnu informaciju o tomu kako su određene mjere prihvaćene među određenom grupom te vrlo argumentirane prijedloge za njihovo daljnje razvijanje, kao i vrlo stručno znanje

13 Guéguen, op. cit., str. 16.

14 U ovoj fazi dolazi i do potpisivanja temeljnih ugovora za Europsku uniju: 1992. godine potpisan je Ugovor o Europskoj uniji, poznat i kao Ugovor iz Maastrichta (stupa na snagu 1993.); godine 1997. potpisan je Ugovor iz Amsterdama koji stupa na snagu dvije godine kasnije, a 2001. potpisan je Ugovor iz Nice koji je na snazi od 2003. Konačno, 2006. započinje posljednja faza koja traje sve do danas, a u kojoj je potpisan Sporazum iz Lisabona ili tzv. Reformski ugovor koji je stupio na snagu 2009.

15 Guéguen., op. cit., str. 16.

16 Ibid., str. 17.

17 Vidačak, Igor, Lobiranje, Interesne skupine i kanali utjecaja u Europskoj uniji, Planetopija, Zagreb, 2007., str. 12.

18 Loc. cit. 
iz određenog područja, što je, nažalost, nerijetko stavljeno po strani pri evaluaciji učinaka lobiranja. Uz to, stalna je tendencija porasta broja aktera ovog procesa, što se može objasniti i proširenjem Unije na nove članice, ali i proširenjem područja javnih politika Unije. ${ }^{19}$ Doista, na karti svijeta lobiranja Bruxelles se smješta odmah iza Washingtona po broju i koncentraciji lobista, a iako su procjene vrlo različite, uglavnom se kreću oko 15 tisuća lobista, a neke se penju čak i do 30 tisuća. ${ }^{20}$ Područje oko EU institucija u Bruxellesu naziva se i „Brusslington“, ${ }^{21}$ što implicira ključnu ulogu koju EU igra pri omogućavanju korporacijama i organizacijama utjecaj i oblikovanje legislative i regulative u područjima trgovine i okoliša. ${ }^{22}$

\subsection{Začetci regulacije lobiranja и $E U-u$}

S obzirom na opisanu proliferaciju lobiranja kao posebne djelatnosti, a osobito kako bi se razjasnilo tko lobira za čije interese te čijim sredstvima, pitanje regulacije lobiranja u institucijama EU pokrenuto je koncem osamdesetih godina. Prvim službenim priznanjem lobističkih aktivnosti u EU smatra se izvješće Komisije poznato pod nazivom Cecchini Report, a koje se ticalo jedinstvenog tržišta i koje preporuča da se poslovni interesi aktivnije i izravnije uključe u kreiranje politika Unije. ${ }^{23}$ Međutim, ,,prijedlozi koji su bili na tragu uvođenja sustava akreditacija za interesne skupine, sličnog onome koji postoji u Vijeću Europe ili UN-u“,${ }^{24}$ nikad nisu naišli na odobravanje Komisije. U obavijesti Komisije o otvorenom i strukturiranom dijalogu s interesnim skupinama iz $1992 .{ }^{25}$ ističe se da je opća politika Komisije ne davati povlašten status interesnim skupinama, koji bi uključivao propusnice te poseban pristup informacijama, niti je namjera službeno podupirati određene skupine formaliziranjem njihova savjetodavnog statusa. Prvi dobrovoljni registar lobista uspostavio je Europski parlament dokumentom Rules of Procedure 9(2) ${ }^{26}$ 1996. godine. Europska je komisija tek 2008. godine uspostavila Register of Interest Representatives, kao nadogradnju na European Transparency Initiative (ETI) iz 2005.

19 Primjerice pravo zaštite okoliša, pravo tržišnog natjecanja, zaštita potrošača, itd.

20 Chambers, Anthony, The Lobbying of the EU - How to achieve greater transparency, Civitas: Institute for the Study of Civil Society February 2016, dostupno na: http://www.civitas.org.uk/ content/files/Anthony-Chambers-EU-lobbying.pdf, posjećeno 20.06.2017., str. 5.

21 Neologizam riječi „Bruxelles“ i „Washington“, čime se ukazuje na snažnu moć Bruxellesa kao središta lobiranja u Europi, a aludirajući na položaj Washingtona kao grada s najvećim brojem lobista na svijetu, op.a.

22 Bitonti, A., Harris, Ph., Lobbying..., op. cit. str. 2.

23 Transparency of lobbying at EU level, Briefing, December 2015, dostupno na: http://www. europarl.europa.eu/RegData/etudes/BRIE/2015/572803/EPRS_BRI(2015)572803_EN.pdf, str. 2., posjećeno 20.06.2017.

24 Vidačak, I., op.cit., str. 106.

25 European Commission: An open structured dialog between the Commission and special interest groups, 1992., 93/C63/02, dostupno na: http://eur-lex.europa.eu/legal-content/EN/TXT/ $\mathrm{PDF} /$ ?uri=OJ:JOC_1993_063_R_0002_01\&from=EN, posjećeno 28.2.2018.

26 European Parliament: Parliament's Rules of Procedure 9(2), 1996., dostupno na: http:// www.europarl.europa.eu/sides/getDoc.do?type=REPORT\&reference=A4-19960200\&language=EN, posjećeno 28.02.2018. 
godine, a registar Parlamenta i Komisije objedinjen je 2011. godine u Joint European Transparency Register (TR), koji, međutim, nije obvezatan.

\subsection{Europska inicijativa za transparentnost}

Pitanje transparentnosti lobiranja bilo je jedno od ključnih od samih početaka Inicijative, a za koje se najveće zasluge pridaju estonskom članu Komisije te povjereniku za administrativna pitanja i suzbijanje prijevara, Siimu Kallasu, kasnije i potpredsjedniku tijekom Barrosovih predsjedavanja Komisijom. Europska inicijativa za transparentnost (ETI) formalno je usvojena 9. studenog 2005. godine, a imala je za cilj ,ponovno povezati Europu s njenim građanima te zatvoriti fizički i mentalni

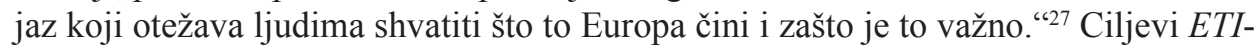
ja su bili „povećati otvorenost i pristupačnost institucijama EU, povećati svijest o trošenju proračuna EU te učiniti institucije EU odgovornijima javnosti. “28 Nakon brojnih debata, Zelena knjiga za ETI usvojena je 3. svibnja 2006. godine, a 21. ožujka 2007. godine Komisija objavljuje svoja stajališta i zaključke nakon provedenih konzultacija. ${ }^{29}$ Europska inicijativa za transparentnost predviđala je dobrovoljnu registraciju interesnih grupa budući da pojam lobista nije bio jasno definiran pa se koristio širi pojam, a nisu se zahtijevala ni osobna imena pojedinaca, već samo kompanije ili organizacije koju su predstavljali. Kao glavni nedostatci ETI-ja najčešće se spominju ,nedovoljno poticajan dobrovoljni sustav za registraciju lobista; nejasan sustav monitoringa i sankcija za kršenje kodeksa; izostanak obveze podnošenja financijskih izvješća i navođenja popisa klijenata; neadekvatno rješavanje 'fenomena okretnih vrata' (revolving doors); slabosti samoregulacije lobista“".30

Sve je to rezultiralo daljnjim raspravama i iskristaliziralo potrebu za povećanjem transparentnosti. Tako Parlament 2008. godine donosi rezoluciju o Razvoju okvira za aktivnosti lobista u institucijama EU-a ${ }^{31}$ a Komisija iste godine uspostavlja Registar zastupnika interesa, ${ }^{32}$ i to u vrijeme kada je Siim Kallas potpredsjednik Komisije. Organizacije upisane u Registar trebaju navesti tko su te koji su njihovi ciljevi i namjere, koja ih područja politika (policy) ponajviše interesiraju, a mogu opisati i svoje glavne aktivnosti kao zastupnika interesa. Također se uvodi objava financijskih informacija, kako bi bile poznate i pokretačke snage iza lobističkih pokušaja. Na

27 ALTER-EU, The European Transparency Initiative and ALTER-EU, https://www.alter-eu.org/ about/coalition, posjećeno 20.6.2017.

28 Loc. cit.

29 Holman, Craig, Lobbying Reform in the United States and European Union: Progress on Two Continents, Public Citizen, 2009., str. 6.

30 Vidačak, Igor, Lobiranje u Europskoj uniji, Powerpoint prezentacija, http://www.emins.org/ pmlr/download/Igor\%20Vidacak_lobiranje-EU.pdf, posjećeno 20.06.2017., str. 13 .

31 Europa, Registar transparentnosti, ključni datumi, http://ec.europa.eu/ transparencyregister/public/staticPage/displayStaticPage.do;TRPUBLICID-prod $=5$ gH3BPKGgTQsiUxtqDzwv7UNnRTcpME-JkTyxS6kKgjNwLqzZet!925169321?locale=hr\&r eference=KEY_DATES, posjećeno 20.06.2017.

32 European Commission, Press releases database, Press Release details, Commission's lobby register: it's time to sign up, dostupno na: http://europa.eu/rapid/press-release_IP-08-988_ hr.htm?locale=en, posjećeno 20.6.2017. 
zahtjev trećih strana lobističke organizacije moraju navesti i imena svojih klijenata. Pri registraciji potrebno je prihvatiti Kodeks ponašanja koje je donijela Komisije. On postavlja općenite kriterije poput otvorenosti, iskrenosti i integriteta koji bi trebali biti misao vodilja zastupnika interesa u njihovu ophođenju s Komisijom, no propisuje i sedam nedvojbenih pravila ponašanja ${ }^{33}$ koja valja poštovati.

\subsection{Registar transparentnosti Europskog parlamenta i Europske komisije}

Pravni temelj objedinjenog registra transparentnosti (Joint European Transparency Register) iz 2011. godine jest Međuinstitucijski sporazum Europskog parlamenta i Europske komisije o registru transparentnosti za organizacije i samozaposlene osobe koje sudjeluju u oblikovanju i provedbi politike EU-a. ${ }^{34}$ Njegovo područje primjene, prema čl. 7., uključuje sve aktivnosti „,...) koje se obavljaju radi izravnog ili neizravnog utjecanja na oblikovanje ili provedbu politike te na postupke odlučivanja institucija EU-a, bez obzira na mjesto njihova provođenja i korišteni kanal ili način komunikacije, primjerice uporabu vanjskih usluga, medija, ugovora sa stručnim posrednicima, trustova mozgova, platforma, foruma, kampanja i lokalnih inicijativa." Izravni utjecaj znači utjecanje putem izravnog kontakta ili komunikacije s institucijama EU-a ili druga radnja nastavno na takve aktivnosti. Neizravni podrazumijeva utjecaj putem posrednih prijenosnika utjecaja, poput medija, javnog mnijenja, konferencija ili društvenih događaja koji ciljaju na institucije EUa. Te aktivnosti posebice uključuju: održavanje kontakta sa zastupnicima i njihovim pomoćnicima, dužnosnicima ili drugim osobljem institucija EU-a; pripremu, slanje i dostavljanje pisama, informativnog materijala ili dokumenata za raspravu i zauzimanje stajališta; organizaciju događaja, susreta, promotivnih aktivnosti, konferencija ili društvenih događaja te slanje pozivnica zastupnicima i njihovim pomoćnicima, dužnosnicima ili drugom osoblju institucija EU-a; kao i dobrovoljne doprinose i sudjelovanje na službenim savjetovanjima ili saslušanjima o predviđenim zakonodavnim aktima ili drugim pravnim aktima EU-a i sudjelovanje na drugim otvorenim savjetovanjima.

Provedba Registra u nadležnosti je glavnih tajnika Europskog parlamenta

33 Riječ je o sljedećim pravilima: 1. identificirati se po imenu i entitetu za koji rade ili koji predstavljaju; 2. ne se lažno predstavljati radi dovođenja u zabludu treće osobe i/ili osoblja EUa; 3. obznaniti koje interese, a kada je primjenjivo i koje klijente zastupaju; 4. osigurati da su, prema njihovom najboljem saznanju, informacije koje pružaju nepristrane, potpune, ažurirane i ne dovode u zabludu; 5 . ne dobiti ili pokušati dobiti informacije, ili bilo kakvu odluku, nepošteno; 6. ne poticati osoblje EU-a da prekrši pravila i standarde ponašanja koji se primjenjuju na njih; 7. ako zapošljavaju bivše zaposlenike EU-a, trebaju poštovati njihovu obvezu pridržavanja pravila i uvjeta povjerljivosti koji se primjenjuju na njih; European Commission for Democracy Through Law (Venice Commission) Report on the Legal Framework for the Regulation of Lobbying in the Council of Europe Member States, dostupno na: http://www.venice.coe.int/ webforms/documents/default.aspx?pdffile=CDL-DEM(2011)002-e, Strasbourg, 31 svibnja 2011., posjećeno 5.3.2018., str. 12.

34 Službeni list Europske unije, L 277/11., dostupno na: http://eur-lex.europa.eu/legal-content/ HR/TXT/PDF/?uri=CELEX:32014Q0919(01)\&from=hr, posjećeno 20.6.2017. 
i Europske komisije. ${ }^{35}$ Zadaće Tajništva su svakodnevno upravljanje registrom, provjera izjava, odgovaranje na upite, poduzimanje mjera kao odgovor na upozorenja i pritužbe, poboljšanje kvalitete podataka u registru, jačanje svijesti u institucijama EU-a i izvan njih. Zajedničko tajništvo također zadržava pravo da iz registra izbriše svaki subjekt čije su vrijednosti, ciljevi, aktivnosti i/ili djelovanja proturječne temeljnim vrijednostima EU-a kako je utvrđeno u članku 6. stavcima 1. i 2. Ugovora o EU-u. Tajništvo nadzire kvalitetu sadržaja registra i zadržava pravo osporavanja upisa subjekta u registar ako ne postoji razlog za njegovo upisivanje. Isto važi i za izjave koje su sastavljene tako da promiču predmetnu organizaciju ili sadržavaju proizvoljne izjave koje nisu činjenično utemeljene.

U prilogu 3. Sporazuma sadržan je Kodeks ponašanja za sve one koji se upisuju $\mathrm{u}$ registar te se uspostavljaju temeljna načela za norme ponašanja u svim odnosima s institucijama EU-a. Ukoliko dođe do povreda Kodeksa, uspostavljen je mehanizam upozorenja i pritužbi putem kojeg se dotično ponašanje može prijaviti pomoću odgovarajućeg obrasca na mrežnoj stranici registra. Upozorenje o ,činjeničnoj pogrešci među informacijama upisanima u registar ${ }^{\star 636}$ može unijeti svaka osoba, a moguće je čak upozoriti i na irelevantne unose. Pritužbe su službene, dakle, nešto su ozbiljniji mehanizam i potrebno ih je potkrijepiti dokazima. Njih se podnosi ako se smatra da nisu poštovana pravila Kodeksa, a ako se osobe upisane u registar ili njihovi predstavnici namjerno ne pridržavaju Kodeksa ponašanja, provode se mjere utvrđene u Prilogu IV. U slučaju opetovane nesuradnje, neprimjernog ponašanja ili ozbiljnog kršenja kodeksa ponašanja, upisana osoba briše se iz registra na godinu ili dvije godine. Nadležno tijelo je, kao što smo napomenuli, JTRS (Joint Transparency Register Secretariat), odnosno Tajništvo zajedničkog registra transparentnosti.

U registru transparentnosti je 1. svibnja 2018. godine bilo upisano 11.743 subjekata. U prvoj kategoriji, koja obuhvaća pružatelje usluge savjetovanja, odvjetnička društva i samozaposlene savjetnike, bilo je 1284 subjekata, a u sljedećoj, najbrojnijoj, kategoriji, koju sačinjavaju interni lobisti i trgovinska/poslovna/strukovna udruženja, ukupno je 5.804 upisanih subjekata. Nevladinih organizacija bilo je 3.097, a trustova mozgova, istraživanja i akademskih ustanova koji su objedinjeni pod četvrtom kategorijom upisano je 920. Organizacija koje zastupaju crkve i vjerske zajednice bilo je upisanih 50, dok je u posljednjoj kategoriji, koju sačinjavaju organizacije koje zastupaju lokalna, regionalna i općinska tijela, druge javne ili javno-privatne subjekte i sl., bilo $588 .^{37}$

35 Sukladno čl. 22. Sporazuma, Registar vodi Zajedničko tajništvo Registra transparentnosti, a u njemu su zaposlenici i Komisije, i Parlamenta.

36 Europa, Registar transparentnosti, dostupno na: http://ec.europa.eu/transparencyregister/ public/homePage.do?redir=false\&locale $=\mathrm{hr}$, posjećeno 20.6.2017.

37 Na datum 1.12.2015. u Registru je bilo 8728 registriranih subjekata (prema: Transparency of lobbying..., op. cit., str. 4.), a procjenjuje se da je u njemu upisano $75 \%$ poslovnih organizacija i oko $60 \%$ nevladinih organizacija, pa je razvidan trend povećanja upisa u Registar. Statistički podatci preuzeti sa službene mrežne stranice Registra transparentnosti 1. svibnja 2018., dostupno na: http://ec.europa.eu/transparencyregister/public/homePage.do?redir=false\&locale=hr, posjećeno 01.05.2018. 


\subsection{Budućnost regulacije lobiranja u $E U$-u}

Europski parlament kontinuirano iskazuje težnje za uvođenjem obveznog registra transparentnosti. Predsjednik Komisije Jean Claude Juncker, 2014. godine stavlja pitanje transparentnosti lobiranja u političku agendu, obećavajući da će do 2016. biti podnesen i zahtjev za obveznom registracijom. Antikorupcijsko izvješće Europske unije iz 2014. godine objašnjava važnost transparentnosti lobiranja, navodeći da je u cjelokupnoj kompleksnosti kreiranja javnih politika poželjno da javna uprava bude uključena u dijalog s vanjskim dionicima te bi sve zainteresirane strane trebale imati pravo izraziti svoje mišljenje, no na transparentan način, kako bi se smanjio rizik korupcije, a to je moguće kroz zakonodavstvo ili mehanizme registracije. ${ }^{38}$ Nadalje, Komisija je napravila i važan pothvat glede transparentnosti lobiranja. Uvela je praksu objavljivanja informacija koje se tiču sastanaka održanih između lobista i članova Komisije, njihovih ureda i izvršnih direktora. ${ }^{39}$

Što se Europske unije tiče, moguće je, dakle, identificirati četiri glavne preokupacije povezane s aktivnosti lobiranja: utvrđivanje točnog broja interesnih grupa koje lobiraju u EU institucijama, informacije o tipologiji interesnih grupa, informacije o troškovima lobiranja te utvrđivanje sukoba interesa. ${ }^{40} \mathrm{U}$ tom je smislu vrlo značajna novina od 28. rujna 2016. godine, a to je prijedlog Komisije o obveznom registru transparentnosti i to za sve institucije EU: i Parlament, i Komisiju, i Vijeće. Frans Timmermans, tadašnji prvi potpredsjednik Komisije, nakon što je Komisija predložila strožu regulaciju lobiranja, ${ }^{41}$ izjavio je: „Predlažemo jednostavno pravilo: nema sastanaka s donositeljima odluka bez prethodnog upisa u registar. Javnost će putem registra vidjeti tko lobira, koga predstavljaju i koliko troše." Naime, otkako je Komisija 2014. godine uvela prethodni upis u registar transparentnosti kao preduvjet za ostvarivanje kontakta s njezinim članovima, zabilježeno je čak četiri tisuće novih upisa. Radi što veće djelotvornosti, Komisija je spremna osigurati i dodatna sredstva i djelotvornije mehanizme praćenja poštovanja Kodeksa ponašanja. ${ }^{42}$ Istodobno, preko stotinu udruga i organizacija civilnoga društva (predvođenih s ALTER-EU, Civil Society Europe i Transparency International EU) uputilo je 17. ožujka 2017. godine otvoreno pismo zastupnicima u Parlamentu pribojavajući se umanjenja učinaka Registra urgirajući da zastupnici pri pregovorima zagovaraju sljedeće stavke: sastanke

38 Report from the Commission to the Council and the European Parliament - EU Anti-Corruption Report, Brussels, 3.2.2014., dostupno na: https://ec.europa.eu/home-affairs/sites/homeaffairs/ files/e-library/documents/policies/organized-crime-and-human-trafficking/corruption/docs/ acr_2014_en.pdf, posjećeno 10.7.2018., str. 20.

39 Transparency of lobbying..., op. cit., str. 3.

40 Loc. cit.

41 Reuters, EU executive proposes tighter lobbying rules, 28. rujna 2016., dostupno na: https://www.reuters.com/article/us-eu-ethics-lobbying/eu-executive-proposestighter-lobbying-rules-idUSKCN11Y2PW, posjećeno 28.2.2018.

42 „Subjekti upisani u registar koji ne budu poštovali pravila kodeksa ponašanja mogli bi se suočiti s privremenim ukidanjem svojih interakcija s institucijama ili uklanjanjem iz postojećeg registra." Europska komisija - Priopćenje za tisak, Ostvarenje transparentnosti: Komisija predložila obvezni registar transparentnosti za sve institucije EU-a, dostupno na: http://europa. eu/rapid/press-release_IP-16-3182_hr.htm, posjećeno 20.06.2018. 
samo s registriranim lobistima, dodjela financijska sredstva Zajedničkom tajništvu radi osiguravanja kvalitete podataka, zadržavanje trenutne definicije lobiranja, koja uključuje i izravno i neizravno lobiranje te obvezu stvaranja pravno obvezujućeg i dugoročnog registra ${ }^{43} \mathrm{Na}$ tom tragu Komisija je i formalno usvojila novi Kodeks ponašanja za članove Komisije. Najvažnije novine su produljenje perioda „hlađenja“ s 18 mjeseci na dvije godine za bivše članove Komisije te na tri godine za bivšeg predsjednika Komisije. Prvi je put definiran sukob interesa i opisane su situacije koje bi se potencijalno mogle podvesti pod taj pojam, a članovi Komisije moraju prijavljivati svaku donacije iznad 10.000,00 eura, neovisno o tomu je li riječ o potencijalnom sukobu interesa ili ne. Podatci o putnim troškovima članova Komisije prvi put su objavljeni 28. veljače 2018. (za svakog člana Komisije dostupni su podatci o izdatcima za putovanje, smještaj, dnevnice te podatci o ostalim troškovima), ${ }^{44}$ a putovanja bi se trebala odvijati na najekonomičniji način. Velika je novina i u području primjene pravila, te će sada u radu pripomagati i nezavisni Neovisni etički odbor (Independat Ethical Committee) koji će biti ovlašten savjetovati i davati preporuke u odnosu na sva pitanja povezana s Kodeksom. U slučaju kršenja pravila koje ipak ne zahtijeva da predmet dođe do Suda EU, Komisija može izreći opomenu te je obznaniti javnosti. Članovima Komisije je omogućeno i kandidiranje u Parlamentu bez uzimanja dopusta, što će se primjenjivati nakon što Parlament pristane ažurirati Okvirni sporazum između Parlamenta i Komisije. Radi povećanja transparentnosti, Komisija će objavljivati i godišnja izvješća o primjeni Kodeksa. ${ }^{45}$

\section{PRAVNA REGULACIJA LOBIRANJA U DRZ̆AVAMA ČLANICAMA EUROPSKE UNIJE}

U Bruxellesu je prepoznata nužnost regulacije lobiranja kao legalne i za demokratski proces vrlo bitne aktivnosti, a osobito radi važnosti transparentnosti i javne dostupnosti informacija. Međutim, kada je riječ o pojedinim članicama Unije, situacija je vrlo različita i šarolika. Razlozi tomu su mnogobrojni, no zasigurno pravni okvir zemlje, politička kultura, odnosno kolektivna svijest igraju bitnu ulogu kada je riječ o pravnoj regulaciji lobiranja i njegovoj transparentnosti. Ipak, opće je prihvaćeno da su sheme za regulaciju lobiranja izvedene iz brige o deficitu demokratičnosti, otvorenosti i transparentnosti vlasti, jednakosti i mogućnosti za pristupanje odnosima s javnošću te stalnoj potrebi za upravljanjem protokom informacija prema i od vlasti. ${ }^{46}$

43 Civil Society Europe, The European Parliament must do more to improve lobby, transparency, dostupno na: https:/civilsocietyeurope.eu/2017/03/17/the-european-parliament-must-domore-to-improve-lobby-transparency/, posjećeno 20.6.2018.

44 Access Info Europe: European Commission starts publishing travel expenses proactively, dostupno na: https://www.access-info.org/article/30403, posjećeno 22.4.2018.

45 European Commission - Press release, New Code of Conduct strengthening ethical rules for Members of the European Commission enters into force, Brussels, 31 January 2018, dostupno na: http://europa.eu/rapid/press-release_IP-18-504_en.htm, posjećeno 26.2.2018.

46 Bitonti, A., Harris, P., Lobbying..., op. cit., str. 11. i Greenwood, Justin i Thomas, Clive S., Regulating lobbying in the western world, Parliamentary Affairs, 51 (4), 1998., str. 487-499. te Chari, Raj, Murphy, Gary, Hogan, John, Regulating lobbyists: A comparative analysis of 
Osim toga, određeni regulativni model ne može biti jednostavno transferiran u drugu državu.

U već postojećim zakonodavstvima o lobiranju postoje i određeni propusti, no često je zapravo „samo“ potrebna bolja implementacija, ne nužno i kompletan redizajn trenutnih regulatornih politika. Ne treba zaboraviti činjenicu da je lobiranje imanentno demokraciji, a različiti tipovi demokratskih sustava, pravila, običaja i sl., rezultiraju i različitim vrstama lobiranja. Baš zato, čak i da postoji savršen model, bilo bi gotovo utopistički očekivati da će on proizvoditi iste učinke u nekoj drugoj državi. Upravo zbog toga regulaciju lobiranja ne treba proučavati per se, već u općenitijoj perspektivi aktualnog sustava interesnih grupa te političkog i institucionalnog okvira. Prema podatcima Europskog parlamenta o trenutnom stanju u državama EU-a ${ }^{47}$ zasad je samo osam država članica donijelo zakonodavstvo o lobiranju te uvelo obveznu registraciju: Francuska, Irska, Litva, Austrija, Poljska, Nizozemska, Slovenija te, još službeno članica, Ujedinjeno Kraljevstvo. U Njemačkoj, Italiji i Rumunjskoj registracija je dobrovoljna. Belgija, Luksemburg, Danska, Estonija, Švedska, Slovačka, Bugarska, Grčka, Mađarska, Cipar, Malta, i Portugal nemaju niti zakonodavstvo o lobiranju, niti kodeks ponašanja, pa čak ni registar lobista.

U daljnjem tekstu bit će prikazana zakonodavstva pojedinih država članica EUa. ${ }^{48}$

\subsection{Baltičke dř̆ave i Poljska}

Litva i Poljska prednjačile su po uvođenju zakona o lobiranju, a „koji se uvelike oslanja na model prihvaćen u SAD-u“ “99 Predmetni se zakoni mogu okarakterizirati kao relativno kratki, a reguliraju pitanja kao što su: „definicija lobiranja odnosno lobističke djelatnosti, lobisti i njihovi klijenti, popis odgovornosti i prava lobista, obilježja lobističkog registra, izvještavanje o lobističkoj aktivnosti i, napokon, katalog kaznenih odredbi s predviđenim sankcijama za kršenje zakona." ${ }^{\text {50 }}$

$\mathrm{Na}$ estonskom tržištu postoji na desetke kompanija koje se bave lobiranjem, no

the United States, Canada, Germany, and the European Union, The Political Quarterly, 78 (3), 2007., str. 422-438.

47 Grosek, Kristina, Claros, Eulalia, Regulation of lobbying across the EU, European Parliamentary Research Service, Members' Research Service, dostupno na: http://www.europarl.europa. eu/RegData/etudes/ATAG/2016/595830/EPRS_ATA(2016)595830_EN.pdf, posjećeno 21.6.2018.

48 O RH će biti detaljnije raspravljano u drugom radu budući da kompleksnost političke i društvene pozadine u kojoj se lobiranje svakodnevno odvija zahtijeva podrobnu analizu. Ovdje ipak valja reći da još uvijek nije donesen zakonski tekst koji bi uspostavio pravila i dopuštena ponašanja lobiranja u našoj državi. Trenutno lobiranje svoje uporište nalazi u članku 46. Ustava RH (opće pravo peticije). Prijedlog Zakona o zagovaranju interesa upućen je Hrvatskom saboru još 2015. godine i ostao je bez odaziva. Strategija suzbijanja korupcije za razdoblje od 2015. do 2020. godine (točka 5.1.1. te mjera 3.) navodi da bi upravo regulacija lobiranja omogućila priznanje i uspostavu lobiranja kao legalne i legitimne profesije.

49 Vidačak, I., Lobiranje..., op. cit., str. 118.

50 Loc. cit. 
koje ipak neće svoje djelatnosti reklamirati kao takve zbog straha od društvene stigme. ${ }^{51}$ Zbog nedostatka i pravne regulacije lobiranja te javne rasprave o etičnosti lobiranja, Bintonti smatra kako lobiranje u Estoniji može biti i izazov za demokraciju. ${ }^{52} \mathrm{U}$ Latviji se lobiranje uglavnom odvija u sferama ekstenzivne regulacije poput bankarstva, kockanja, industrije alkoholnih pića te u javnim investicijama pa, shodno tomu, u toj državi prevladavaju korporativni lobisti. ${ }^{53}$ Lobiranje nije uređeno posebnim aktom, no pojedini aspekti podliježu zakonskoj regulativi u kontekstu transparentnosti, osobito u pogledu savjetovanja sa zainteresiranom javnošću pri donošenju propisa i sprječavanja sukoba interesa.

\subsection{Države središnje Europe}

Prvi zakon kojim se uređuje odnos interesnih grupa i javnih dužnosnika Austrija je donijela u srpnju 2012. godine (na snazi od 1. siječnja 2013. godine). ${ }^{54} \mathrm{Njime}$ se uspostavlja obveznost registracije i formalan set pravila koja uključuju pretpostavke registracije koju je potrebno izvršiti prije početka lobiranja, ali i određeni zahtjevi glede objave financijskih podataka te sankcije za nepridržavanje odredaba. Istraživanje koje je provela agencija Donath-Burson-Marsteller i Factum Invenio 2005. godine među političarima u Češkoj, pokazalo je iznenađujući, očit nedostatak znanja i hitnu potrebu za regulacijom lobiranja. Pokušaji regulacije lobiranja nisu rezultirali usvajanjem pa se i u Akcijskom planu za borbu protiv korupcije za 2016. ističe nužnost buduće i što skorije regulacije lobiranja. ${ }^{55} \mathrm{U}$ Mađarskoj je dobrovoljni registar lobista bio uveden još 1994. godine. Nacrt Zakona o lobiranju usvojen je 2006. godine, „nakon neuspjelog pokušaja i niza nesuglasica koje je izazvao prvi nacrt. ${ }^{\text {"56 }}$ I zakonodavstvo o lobiranju i registar opozvala je 2011. godine tadašnja mađarska vlada. Iako pojedini propisi djelomično uređuju lobiranje, nedostaje ozbiljan pravni okvir toga područja. ${ }^{57}$ Pravilnik njemačkoga Bundestaga ${ }^{58}$ predviđa sustav regulacije svih interesnih skupina koje žele zastupati svoje interese pri Bundestagu ili institucijama Savezne vlade.

51 Bitonti, A., Harris, Ph.: Lobbying ..., op.cit., str. 123.

52 Transparency International, Lobbying in Estonia, Mapping the Players, Risks And Political Context, str. 4, dostupno na: http://transparency.ee/cm/files/lisad/lobbying_in_estonia.pdf, posjećeno 11.3.2018.

53 Bitonti, A., Harris, Ph., Lobbying ..., op. cit., str. 219. - 222.

54 Bundesgesetz zur Sicherung der Transparenz bei der Wahrnehmung politischer und wirtschaftlicher Interessen (Lobbying- und Interessenvertretungs-Transparenz-Gesetz - LobbyG), dostupno na: Bundeskanzelaramt, https://www.ris.bka.gv.at/Dokument. wxe? Abfrage=Bundesnormen\&Dokumentnummer=NOR40141416, posjećeno 9.3.2018.

55 Ibid., str. 103-109. i Anti-corruption fight in the Czech Republic, dostupno na: http://www. korupce.cz., posjećeno 2.1.2018.

56 Vidačak, I., Lobiranje..., op. cit., str. 118.

57 Association of Accredited Public Policy Advocates to the European Union, Lobbying Landscape in Hungary, dostupno na: http://www.aalep.eu/lobbying-landscape-hungary, posjećeno 01.07.2018.

58 Anlage 2 der Geschäftsordnung des Deutschen Bundestages - Registrierung von Verbänden und deren Vertretern, dostupno na: http://www.bundestag.de/parlament/aufgaben/rechtsgrundlagen/ go_btg/anlage2/245180, posjećeno 02.07.2018. 
Registar je dobrovoljan i javan, a njegov se sadržaj objavljuje jednom na godinu u službenom listu. ${ }^{59} \mathrm{U}$ njemačkoj saveznoj zemlji Saska-Anhalt od 2014. godine postoji obvezna registracija za entitete koji lobiraju u parlamentu te savezne zemlje, a 8 . ožujka 2017. godine njemačkom je parlamentu podnesen prijedlog s 180.000 potpisa za uvođenjem obvezne registracije. ${ }^{60}$ Iako lobiranje u Slovačkoj, unatoč pokušajima, nije regulirano zakonom, Slovačka je ipak učinila značajne korake k uvođenju novih elemenata u području transparentnosti, kao što su online poslovni registar te zakonske odredbe o pravu na slobodu, odnosno pristup informacijama. ${ }^{61}$

Posebno je zanimljiv slučaj Slovenije u kojoj je lobiranje regulirano posebnim zakonom - Zakon o integriteti in preprečevanju korupcije (ZIntPK). ${ }^{62}$ Naime, ova država lobiranje smješta u kontekst borbe protiv korupcije, a prema izvješću Transparency Internationala, polučila je najkvalitetniji zakon o lobiranju u usporedbi s devetnaest europskih zemalja, pa čak i u usporedbi s institucijama kao što su Komisija ili Parlament. ${ }^{63}$ Pitanje regulacije lobiranja izazvalo je svojedobno brojne rasprave i s etičke, i s pravne strane. Prevladalo je mišljenje da je lobiranje dio demokratskog procesa te potpada pod temeljna prava zajamčena Ustavom, primjerice, dio je slobode govora, prava na udruživanje i organiziranje, kao i prava na sudjelovanje građana $u$ kreiranju javnih politika, prava na slanje predstavki i pritužbi te ostalih pitanja od općeg značaja, ali i slobode trgovinskih udruženja.

\subsection{Drăave zapadne Europe}

Najrecentniji zakonski akt usvojen je u Francuskoj 8. studenog 2016. godine, a poznat je pod nazivom Loi Sapin $I I,{ }^{64}$ prema pokrovitelju prvoga takvog akta, ministru financija Micheleu Sapinu. Francuska je prihvatila koncept obvezne registracije lobista. Obveznici registracije su javne ili privatne organizacije uključene u industrijske ili trgovačke aktivnosti, industrijske, trgovačke te obrtničke komore,

59 Službena (amtliche Fassung) te trenutačna verzija (aktuelle Fassung) mogu se posjetiti putem internetske stranice Parlamenta. Vidačak, I., Lobiranje..., op. cit., str. 118.

60 Library of Congress, Lobbying Disclosure Laws: Germany, dostupno na: https://www.loc. gov/law/help/lobbying-disclosure/germany.php, posjećeno 1.7.2018.

61 Bitonti, A., Harris, Ph., Lobbying ..., op. cit., str. 293-296.

62 Zakon o integriteti in preprečevanju korupcije (ZIntPK), Uradni list RS, št. 69/11 - uradno prečiščeno besedilo), dostupno na: http://www.pisrs.si/Pis.web/pregledPredpisa?id=ZAKO 5523, posjećeno 9.7.2018.

63 Transparency International Slovenia, Lifting the Lid on Lobbying: Slovenia Call for Transparent and Ethical Lobbying, Transparency International Slovenia - Društvo Integriteta, Ljubljana, 2014., dostupno na: http://www.transparency.si/images/publikacije/lobiranje/report lobbyinginslovenia.pdf, posjećeno 01.07.2018., str. 13. Vidi i: Republic of Slovenia, Government of the Republic of Slovenia, News, Slovenia with the best quality of lobbying regulation in Europe, dostupno na: http://www.vlada.si/en/media_room/newsletter/slovenia_weekly/news/ article/slovenia_with_the_best_quality_of_lobbying_regulation_in_europe_52774/, posjećeno 1.7.2018.

64 Projet de loi relatif à la transparence, à la lutte contre la corruption et à la modernisation de la vie économique, dostupno na: http://www.assemblee-nationale.fr/14/ta/ta0830.asp, posjećeno 10.7.2017. 
kao i pojedinci izvan navedenih djelatnosti i komora ako se bave lobiranjem. ${ }^{65}$ Iako neobjavljivanje traženih informacija može rezultirati kaznom zatvora u trajanju do jedne godine i kaznom do 15.000 eura, mnoge organizacije na čelu s ALTER-EU kritiziraju iznos kazne, smatrajući ga zanemarivim u odnosu na stotine tisuća ili čak milijune eura ostvarenoga prihoda. ${ }^{66}$

Irska je 1. rujna 2015. godine usvojila Registration of Lobbying Act ${ }^{67}$ kojim su uređena pitanja kao što su tko lobira, na čiji se zahtjev lobiranje odvija, prema kome je ono upućeno te očekivani rezultat. ${ }^{68}$ Komisija za standarde (The Standards Commission) nadležna je za nadzor lobiranja. U svrhu približavanja lobiranja javnosti i u slučaju dvojbi, može primijeniti The Three Step Test. ${ }^{69}$

U Ujedinjenom je Kraljevstvu 2014. godine donesen Transparency of Lobbying, Non-party Campaigning and Trade Union Administration Act ${ }^{70}$ koji zahtijeva da konzultanti i lobisti objave detalje o sebi kroz javno dostupan registar. ${ }^{71}$ Bavljenje lobističkim aktivnostima bez registracije smatra se kaznenim djelom te je kažnjivo novčanom kaznom. ${ }^{72}$

\subsection{Države Beneluxa}

Zemlje Beneluxa odlikuju određene posebnosti. Nizozemska ima vrlo specifičnu korporativnu tradiciju u procesu donošenja odluka, tzv. Polder-model, koji označava snažnu institucionaliziranu vezu između vlade i organizacija koje imaju ekonomske, socijalne i druge interese. U Nizozemskoj tako postoji House of

65 Library of Congress, Lobbying Disclosure Laws: France, dostupno na: https://www.loc.gov/ law/help/lobbying-disclosure/france.php, posjećeno 10.7.2017.

66 ALTER-EU, The French Parliament passes the Sapin II law: a step forward?, dostupno na: https://www.alter-eu.org/the-french-parliament-passes-the-sapin-ii-law-a-step-forward, posjećeno 10.07.2018.

67 Regulation of Lobbying Act 2015, dostupno na: http:/www.irishstatutebook.ie/eli/2015/act/5/ enacted/en/html, posjećeno 9.7.2018.

68 Lobbying.ie, Summary of the main provisions of the Act, dostupno na: https://www.lobbying. ie/help-resources/information-for-lobbyists/quick-guide-to-the-act/, posjećeno 1.7.2018.

69 Lobbying.ie, The Three Step Test, dostupno na: https://www.lobbying.ie/help-resources/ information-for-lobbyists/am-i-lobbying/, posjećeno 22.4.2018. Prvo se pitanje odnosi na mogućnost svrstavanja u određene „kategorije“ (poput predstavničkog tijela, poslodavca s više od deset zaposlenih, a da se komunikacija odvija na njegov zahtjev, treća osoba koja vrši komunikaciju na zahtjev klijenta koji se svrstava u neku od navedenih kategorija itd.). Drugo pitanje odnosi se na komunikaciju o važnim temama te se one ukratko pojašnjavaju, kao i pojedine kategorije iz prvog pitanja. Posljednje, treće pitanje, odnosi se na izravno ili neizravno komuniciranje s javnim službenikom. Ako se na sva tri pitanja pozitivno odgovori, velika je vjerojatnost da je riječ o lobiranju te se upućuje na daljnje korake, u skladu sa zakonskim obvezama.

70 Transparency of Lobbying, Non-Party Campaigning and Trade Union Administration Act 2014, dostupno na: http://www.legislation.gov.uk/ukpga/2014/4/contents/enacted i http://www. legislation.gov.uk/ukpga/2014/4/introduction, posjećeno 1.7.2018.

71 Library of Congress, Lobbying Disclosure Laws: United Kingdom, https://www.loc.gov/law/ help/lobbying-disclosure/unitedkingdom.php, posjećeno 01.07.2018.

72 Loc. cit. 
Representatives Rules of Procedure ${ }^{73}$ koji se smatra soft regulacijom, a registar je obvezan za pristup parlamentu. Prema nalazima $A A L E P-\mathrm{a},{ }^{74} \mathrm{u}$ Nizozemskoj danas postoji na stotine lobista, dok se još tisuće „bave lobiranjem u slobodno vrijeme“. Mnogobrojne organizacije civilnog društva uključene su u Lobbywatch Netherlands te zahtijevaju od vlade i parlamenta striktnije rješavanje ovog pitanja. ${ }^{75} \mathrm{U}$ Belgiji ne postoji zakonodavstvo ili obvezna registracija za interesne grupe i predstavnike, što upućuje na velik problem transparentnosti. ${ }^{76}$ Veliko Vojvodstvo Luksemburg također nije donijelo zakonodavstvo o lobiranju, kao ni uspostavilo obvezu registracije. Razlog tomu počiva u činjenici male površine Luksemburga, što olakšava stranim kompanijama izravni pristup odgovarajućim donositeljima odluka.

\subsection{Drăave juz̆ne Europe}

Zajedničko obilježje regulacije lobiranja u zemljama južne Europe jest upravo njezin nedostatak te vrlo negativne konotacije povezane s pojmom lobiranja. Ono nije u široj uporabi na Cipru, pa tako ni definirano u pravnom sustavu, a u rijetkim situacijama kada se u medijima govori o lobiranju, obično je riječ o negativnom kontekstu. ${ }^{77} \mathrm{U}$ Malti, najmanjoj članici EU-a, vode se polemike o tomu tko se uopće ima smatrati lobistom te također nije zakonski regulirala lobiranje. Koncept lobiranja nepoznat je i u grčkom pravu te stoga nije ni reguliran, no dugotrajno razočaranje u politiku stvara potrebu za uspostavom mehanizama koji bi omogućili onima, koji se žele baviti utjecanjem na proces donošenja odluka, da to i mogu činiti na institucionalan i formalan način. ${ }^{78}$

Za Italiju je specifična teorija „,modela zmije ${ }^{\text {“79 }}$ koja uspoređuje propise o lobiranju sa „shizofreničnom zmijom“. Kaže se da regulacija lobiranja poput zmije gmiže talijanskim pravnim sustavom kroz razne druge odredbe različitih zakona, a provedba se također smatra „shizofrenom“ budući da su iste odredbe u konačnici napuštene u provedbi. Naime, između 1948. i 2014. predložena su čak pedeset i četiri zakona koja se tiču lobiranja, no prevladava shvaćanje da bi „reguliranje grupa za pritisak bilo ekvivalentno njihovoj legitimacijic" ${ }^{\text {“80 }}$ pa se o samo nekoliko zakona i raspravljalo. U Portugalu ne postoji pravni okvir koji bi regulirao specifična pravila ili registre za grupe za pritisak i njihove aktivnosti, kao ni za pojedince. Ipak, u budućnosti

73 House of Representatives of the Netherlands - Rules of Procedure, dostupno na: https:// www.houseofrepresentatives.nl/sites/default/files/atoms/files/141120-rules_of_procedure.pdf, posjećeno 11.07.2018.

74 Udruga akreditiranih lobista Europske unije, op. a.

75 ALTER-EU, Lobbywatch Netherlands Launched, dostupno na: https://www.alter-eu.org/ lobbywatch-netherlands-launched, posjećeno 10.7.2018.

76 Bitonti, A., Harris, Ph., Lobbying ..., op. cit., str. 59-69.

77 Medijski je prostor uglavnom kontroliran, a Cipar je uz Luksemburg i jedina država EU-a u kojoj ne postoji opći propis o pravu na slobodu informacija, odnosno pristup informacijama. Ibid., str. 89-99.

78 Ibid., str. 174-175.

79 Petrillo, Pier Luigi, Democrazie sotto pressione, Parlamenti e lobby nel diritto pubblico comparato, Milano, 2011. i Bitonti, A., Harris, Ph., Lobbying ..., op. cit., str. 208-211.

80 Bitonti, A., Harris, Ph., Lobbying ..., op. cit., str. 211. 
bi i moglo doći do pomaka s obzirom na recentnija događanja u sferi korupcije u toj državi. ${ }^{81} \mathrm{U}$ španjolskom Ustavu postoji nekoliko odredbi koje prepoznaju izravno sudjelovanje građana i organizacija u procesu donošenja odluka i pružaju pravnu osnovu za regulaciju lobističkih aktivnosti (članak 9.2, 23.1 i 105.b španjolskoga Ustava). U Kataloniji je 2015. godine uspostavljen registar transparentnosti prema posebnom zakonu o transparentnosti, a važno je naglasiti i da je čak četvero od pet nacionalnih stranaka na izborima 2015. godine uvrstilo u svoj program namjeru regulacije lobiranja. ${ }^{82}$

\subsection{Rumunjska i Bugarska}

Mediji u Bugarskoj ustraju u nastojanjima da učine lobiranje transparentnijim pa se termini „lobiranje“ $i$, „lobi“ koriste u pozitivnom smislu kada se odnose na jaču integraciju zemlje u EU, no istodobno je pojam vrlo nejasan kada su u pitanju sektori energetike ili okoliša. Iako Bugarska nije donijela zakon koji bi regulirao lobiranje, donijela je niz zakona u području prava na pristup informacijama, financiranju političkih stranaka, sprječavanju sukoba interesa kao i kriminalizirala trgovanje utjecajem..$^{83}$ Rumunjska tek nakon 2000. godine donosi dva važna zakona u području javnog sudjelovanja u procesu donošenja odluka (2001. i 2003. godine). Između 2002. i 2011. godine bilo je šest nacrta zakona o lobiranju, no niti jedan nije izglasan, uz argumentaciju da postoji već dovoljno zakona na području transparentnosti pa bi,

81 Ibid., str. 263-278. Jedan od većih skandala bio je RioForte, u kojemu je društvo majka portugalski Telecom uprihodilo više od 897 milijuna eura u obveznicama od društva kćeri u financijskim poteškoćama i dugovima. Naime, tužitelji su istaknuli da je bivši premijer Socrates dao građevinskom poduzeću LENA nedopuštene komercijalne pogodnosti u zamjenu za plaćanja primljena putem posrednika (koji su također optuženi) putem švicarskog bankovnog računa. Bivši menadžer na najvišoj razini u banci u državnom vlasništvu Caixa Geral de Depositos također je optužen. Ricardo Salgado, bivši glavni izvršni direktor Banco Espirito Santo (BES), optužen je za plaćanje Socratesu da preuzme Portugal Telecom kako bi se slijedila strategija koju je odredio upravo sam Salgado. Salgado je također optužen za plaćanje bivšeg izvršnog direktora tvrtke Portugal Telecom Zeinal Bave i rukovodećeg Henrique Granadeiro - te su obojica također oboje optuženi. vidi više: Reuters, Portuguese ex-PM Socrates indicted on corruption charges, https://www.reuters.com/article/us-portugal-corruption-socrates/ portuguese-ex-pm-socrates-indicted-on-corruption-charges-idUSKBN1CG1U5, posjećeno 30.04.2018., Reuters, Prosecutor investigating suspected fraud at Portugal Telecom SGPS, https://uk.reuters.com/article/uk-portugaltelecom-investigation/prosecutor-investigatingsuspected-fraud-at-portugal-telecom-sgps-idUKKBNOKF1BG20150106, posjećeno 30.4.2018., Algarvedailynews, Former PT directors and Deloitte sued over $€ 897$ million Rioforte loan, https://algarvedailynews.com/news/7647-former-pt-directors-and-deloittesued-over-897-million-rioforte-loan, posjećeno 30.04.2018., Politico, https://www.politico.eu/ article/portuguese-backlash-against-plan-to-remove-corruption-busting-prosecutor/, posjećeno 30.4.2018. i sl., Politico, Police search offices of Eurogroup President Mário Centeno https:// www.politico.eu/article/police-search-offices-of-eurogroup-president-mario-centeno/, posjećeno 30.4.2018.

82 Ibid., str. 313-323.

83 Bitonti, A., Harris, Ph.: Lobbying ..., op. cit., str. 71-76. 
umjesto donošenja novih, trebalo unaprijediti provedbu postojećih. ${ }^{84}$

\subsection{Drăave sjeverne Europe}

Danski politički sustav doživio je velike promjene tijekom posljednjih desetljeća pa je tako od pretežno korporativne tradicije, Danska danas postala sinonim za pluralizam gdje ne postoje povlastice za interesne grupe kada je riječ o pristupu donositeljima političkih odluka. Iako uvelike profesionalizirano, lobiranje u Danskoj nije još doseglo stupanj na kojem bi se moglo govoriti o zasebnoj profesiji, kao ni o zakonskoj regulativi. ${ }^{85}$ Lobiranjem u Finskoj tradicionalno prevladavaju poslovna udruženja i različite interesne organizacije, a fenomen ,rotirajućih vrata“"vrlo je izražen te može voditi potencijalnom sukobu interesa u odnosu na ostatak civilnoga društva, a poglavito u kombinaciji s nedostatkom ,,perioda hlađenja“. Trenutno u Finskoj nema prijedloga za zakonskom regulacijom lobiranja, a većina aktera uključenih u proces zalaže se za samoregulaciju. ${ }^{86}$ Politička kultura Švedske opisuje se kooperativnošću, transparentnošću te povezanošću između političara i lobista. Iako se odvija debata o tomu treba li lobiranje biti zakonski uređeno i ako da, u kojem opsegu, za sada rasprave nisu rezultirale donošenjem zakonskoga akta, već se samoregulacija profesije smatra dostatnom i učinkovitom. ${ }^{87}$

\section{DRUGE EUROPSKE MEĐUVLADINE ORGANIZACIJE: VIJECE EUROPE I OECD}

\subsection{Vijeće Europe i lobiranje}

Vijeće Europe međunarodna je organizacija sa sjedištem u Strasbourgu koja trenutno broji četrdeset i sedam država članica te osim Bjelorusije, obuhvaća sve europske zemlje. Budući da su temeljna načela Vijeća Europe ,promicanje ideala i standarda demokracije i pravne države te zaštita i poštivanje ljudskih prava“"88 $\mathrm{za}$ očekivati je da i ova organizacija ima što reći o pravnoj regulaciji djelatnosti lobiranja.

$\mathrm{O}$ ovoj tematici usvojeno je niz preporuka i drugih soft law akata. ${ }^{89}$

84 Ibid., str. 279-289.

85 Ibid., str. 113-120.

86 Ibid., str. 131-141. i Transparency International Finland, dostupno na: https://www. transparency.org/country/FIN, posjećeno 18.12.2018.

87 Bitonti, A., Harris, Ph., Lobbying ..., op. cit., str. 325-331.

88 Statute of the Council of Europe, London, 5.V.1949, dostupno na: https://rm.coe.int/1680306052, posjećeno 1.3.2018.

89 Dokumenti Vijeća Europe koji se izravno tiču tematike lobiranja su Preporuka Parlamentarne skupštine 1908 iz 2010. godine o lobiranju u demokratskome društvu (Parliamentary Assembly Recommendation 1908 (2010) on lobbying in a democratic society), Rezolucija Parlamentarne skupštine 1774 iz 2010. godine o izvaninstitucijskim akterima u demokratskom sustavu te prateće Izvješće 12278 (Parliamentary Assembly Resolution 1744 (2010) on extra-institutional actors in the democratic system, and accompanying Report Doc. 12278), Preporuka Parlamentarne skupštine 2019 iz 2013. godine o korupciji kao prijetnji vladavini prava te prateće izvješće 13228 (Parliamentary Assembly Recommendation 2019 (2013) on corruption as a threat to the 
Najrecentnija Preporuka Vijeća ministara državama članicama o pravnoj regulaciji lobističkih aktivnosti u kontekstu javnog donošenja odluka usvojena je 22. ožujka 2017. godine.$^{90}$ Njome se preporuča da vlade država članica uspostave ili učvrste koherentan i iscrpan okvir za pravnu regulaciju lobističkih aktivnosti u kontekstu donošenja odluka, a u skladu s prilogom preporuci (Appendix to Recommendation CM/ $\operatorname{Rec}(2017) 2)$ te u svjetlu vlastitih nacionalnih zakonodavstava. Pritom se naglašava potreba prevođenja i distribucije Preporuke što je šire moguće, a osobito među, primjerice, interesnim skupinama, trgovačkim i poslovnim udruženjima, javnim tijelima, nevladinim organizacijama te civilnom društvu, kao i među političarima te pripadnicima akademske zajednice. Preporuka navodi kako je temeljni cilj pravne regulacije lobiranja promicanje transparentnosti lobističkih aktivnosti, a regulirane bi trebale biti barem sljedeće situacije: slučajevi kada su konzultanti i lobisti angažirani na zahtjev treće strane, in-house lobisti angažirani na zahtjev svoga poslodavca te organizacije i tijela koja zastupaju profesionalne ili druge (sektorske) interese. Sve iznimke trebaju biti jasno definirane i opravdane. Međutim, pravna regulacija lobističkih aktivnosti ni na koji način ne bi smjela ograničavati demokratska prava pojedinaca na slobodu izražavanja te slanja predstavki i pritužbi javnim službenicima, tijelima i institucijama, bilo individualno ili kolektivno, kao i zagovaranje političkih promjena i promjena zakonodavstva, politike ili prakse, a unutar okvira dopuštenih i legitimnih političkih aktivnosti. Informacije o lobističkim aktivnostima u kontekstu procesa javnog donošenja odluka trebale bi biti objavljene, a pravila o objavljivanju proporcionalna važnosti materije o kojoj je riječ te odražavajući temeljna ustavna jamstva. Registar lobista trebala bi voditi strane nadležna tijela javne vlasti, a podatci u njemu biti deklaratorne naravi. Također, trebao bi biti lako dostupan korisniku, a osobito je bitno da sadržava različite mehanizme pretrage, da je otvoren za javnost i to nenaplatno. Za točnost i ažuriranost podataka odgovorni bi bili sami lobisti, no treba imati na umu propise o zašiti osobnih podataka s kojima bi informacije u registru morale biti usklađene. Lobisti bi se u svome djelovanju trebali voditi otvorenošću, transparentnošću i iskrenošću te se od njih očekuje da pružaju ispravne informacije o svojem djelovanju, djeluju iskreno i u dobroj vjeri, suzdrže se od nedopustivog utjecaja

rule of law, and accompanying Report Doc. 13228), Izvješće Venecijanske komisije o pravnom okviru za regulaciju lobiranja u državama članicama Vijeća Europe (Venice Commission Report $C D L-D E M(2011) 002$ on the legal framework for the regulation of lobbying in the Council of Europe member States), Izvješće Venecijanske komisije o ulozi izvaninstitucionalnih aktera u demokratskom sustavu - lobiranje (Venice Commission Report CDL-AD(2013)011 on the Role of Extra-Institutional Actors in the Democratic System (Lobbying)) te Kaznenopravna konvencija o korupciji (Criminal Law Convention on Corruption (ETS No. 173), and Explanatory Report. 8).

90 Recommendation of the Committee of Ministers to member States on the legal regulation of lobbying activities in the context of public decision making (Adopted by the Committee of Ministers on 22 March 2017 at the 1282nd meeting of the Ministers' Deputies), dostupno na: https://rm.coe.int/legal-regulation-of-lobbying-activities/168073ed69, posjećeno 18.2.2017. Inače, ova je preporuka nastala na temeljima studije izvedivosti Europskog odbora za pravnu suradnju (European Committee on Legal Co-Operation - CDCJ) iz 2014. godine. Preporuci je prethodilo i široko savjetovanje koje je uključivalo predstavnike civilnoga društva, predstavnike iz poslovnog svijeta, kao i iz svijeta politike. 
na javne dužnosnike u procesu donošenja odluka te izbjegavaju sukob interesa. Vijeće Europe također smatra da propisi koji reguliraju lobiranje trebaju sadržavati sankcije za njihovo kršenje, a koje bi trebale biti učinkovite, proporcionalne i odvraćajuće od ponavljanja sankcioniranog djela. Potrebno je predvidjeti i cooling-off period, odnosno vrijeme koje mora proteći prije no što javni dužnosnik može postati lobist, ali vrijedi i obrnuto. Javni dužnosnici trebali bi odbiti ili objaviti darove koje su im ponudili lobisti te objavljivati eventualne sukobe interesa, ali i prijavljivati lobističke aktivnosti koje krše propise ili kodeks ponašanja, imajući na umu povjerljivost podataka. $^{91}$

Sudska praksa Europskog suda za ljudska prava o lobiranju vrlo je oskudna. Tematika se ipak ugrubo dotiče u presudama Dochnal protiv Poljske (2012.), ${ }^{92}$ te OOO Ivpress $i$ ostali protiv Rusije (2013.). ${ }^{93}$ Nije riječ o slučajevima koji bi predstavljali bilo kakav presedan ili iz kojih bi se izvodili drugi važni pravni zaključci o lobiranju, već o slučajevima koji se lobiranja dotiču samo marginalno. Naime, u predmetu Dochnal protiv Poljske podnositelj zahtjeva je poljski lobist i poduzetnik Marek Alojzy Dochnal, a zahtjev se tiče njegove pritužbe na pritvor prije suđenja za dva kaznena postupka, temeljena na optužbama za davanje mita, pranje novca i utaju poreza. Smatrao je da su postupci politički motivirani te da su prekršena njegova temeljna ljudska prava, konkretno čl. 3. i 4. te čl. 18., a čak i čl. 8. U drugom predmetu podnositelj zahtjeva je OOO Ivpress, rusko društvo s ograničenom odgovornošću te dvojica njihovih novinara. Protiv podnositelja zahtjeva vodila su se četiri slučaja na temelju kleveta u novinskim člancima objavljenih u tjedniku Ivanovo-Press između 2003. i 2005. ESLJP je mišljenja kako domaći sud nije dobro odvagnuo činjenice i vrijednosne sudove te postigao ravnotežu između javnog interesa te slobode izražavanja i ugleda, čime je doveden u pitanje čl. 10 Konvencije.

Iz rečenoga je razvidno da Vijeće Europe stalno ističe ${ }^{94}$ važnost regulacije lobiranja zbog znatnog utjecaja koje lobiranje ima na proces donošenja odluka radi uspostave pravila koja se moraju poštovati pri pokušaju utjecaja na ishod javne politike. U suprotnome može doći do podrivanja demokratskih načela te dobre vladavine, no pridajući pažnju i činjenici da pravila o lobiranju treba striktno razlikovati od korupcije kao kaznenog djela. Također, donošenje pravila kojima bi se uredilo lobiranje moglo bi pridonijeti i jačanju povjerenja naroda $u$ politički sustav, s obzirom na to da takva pravila mogu povećati legitimitet političkog sistema, a istovremeno i stvoriti višerazinski prostor za sudjelovanje različitih aktera.

\subsection{OECD i lobiranje}

OECD lobiranje proučava u okviru područja suzbijanja korupcije i osiguranja integriteta djelovanja u javnom sektoru (Anti-corruption and integrity in the public

91 Loc. cit.

92 ECHR, Dochnal v. Poland (no. 31622/07).

93 ECHR, OOO Ivpress and Others v. Russia, (no. 33501/04, 35258/05, 35618/05, 38608/04).

94 Recommendation of the Committee of Minister..., op. cit. 
sector). ${ }^{95}$ Lobiranje smatra demokratskim pravom koje može pružiti vlasti dragocjene spoznaje i podatke te pravom u kojem je sadržana mogućnost građana i interesnih skupina da predstave svoje ideje donositeljima odluka. S druge strane, smatra kako lobiranje može prouzročiti nejednakosti te da je javni interes ugrožen kada se pregovori odvijaju iza zatvorenih vrata. OECD ističe da države nailaze na probleme pri pokušaju regulacije lobiranja zbog kompleksnosti imanentne lobiranju pa se slijedom toga mnoge oslanjaju na samoregulaciju industrije.

Nadalje, Organizacija je izdala brošuru o deset načela za transparentnost i integritet u lobiranju, ${ }^{96}$ koja se svode na četiri glavna područja. To su: izgradnja učinkovitog i pravednog okvira koji omogućuje otvorenost i transparentnost, povećanje transparentnosti, njegovanje kulture integriteta te mehanizme učinkovite implementacije. ${ }^{97}$

U prvo područje ulaze četiri načela: države bi trebale omogućiti svim dionicima pravedan i jednak pristup razvoju i implementaciji javnih politika; pravila i smjernice o lobiranju trebaju izražavati stajališta vlasti o lobističkoj praksi te poštovati socioekonomski i administrativni kontekst; pravila i smjernice o lobiranju trebali bi biti u skladu sa širom politikom i regulatornim okvirom; države bi trebale jasno definirati pojmove lobiranja i lobista pri regulaciji ili unaprjeđenju regulacije lobiranja. U drugu skupinu, povećanje transparentnosti, ulaze načelo prema kojem bi države trebale pružiti odgovarajući stupanj transparentnosti, a s ciljem osiguranja da javni dužnosnici, građani i poduzetnici mogu dobiti opsežne informacije o lobističkim aktivnostima te načelo prema kojem bi države trebale omogućiti dionicima, uključujući organizacije civilnoga društva, poslovnom svijetu, medijima i široj javnosti pomno ispitivanje lobističkih aktivnosti. Treću skupinu čine pravila prema kojima bi države trebale njegovati kulturu integriteta javnih organizacija i procesa donošenja odluka uspostavljanjem jasnih pravila i smjernica ponašanja javnih dužnosnika te da bi lobisti trebali poštivati pravila profesionalizma i transparentnosti - na njima je odgovornost njegovanja kulture transparentnosti i profesionalizma u lobiranju. I, konačno, prema posljednjoj skupini načela, države bi trebale uključiti ključne aktere u implementaciju koherentnog spektra strategija i praksi kako bi se postigla usklađenost te revidirati funkcioniranje svojih pravila i smjernica za lobiranje periodično i činiti potrebne preinake na temelju iskustva u primjeni.

Prvo izvješće ${ }^{98}$ o ovoj tematici, uz stvaranje samog okvira za lobiranje, bavi se i komparativnom analizom regulativa kojima se povećavaju transparentnost i

95 OECD, Lobbying, dostupno na: http://www.oecd.org/gov/ethics/lobbying.htm, posjećeno 19. 1. 2018.

9610 Principles for Transparency and Integrity in Lobbying, dostupno na: http://www.oecd. org/gov/ethics/oecdprinciplesfortransparencyandintegrityinlobbying.htm, posjećeno 18. 1. 2018.

97 Recommendation of the Council on Principles for Transparency and Integrity in Lobbying 18 February 2010 - C(2010)16, dostupno na: https://legalinstruments.oecd.org/Instruments/ ShowInstrument View.aspx?InstrumentID=256\&, posjećeno 11. 1. 2018.

98 Lobbyists, Government and Public Trust, Volume 1, dostupno na: https://read.oecd-ilibrary. org/governance/lobbyists-governments-and-public-trust-volume-1_9789264073371en\#page103.2018., posjećeno 14. 7. 2018. 
odgovornost, a dotiče se i iskustava Kanade (posebno Quebeca) i Poljske. Drugo izvješće, iz 2012. godine, ${ }^{99}$ posvećeno promicanju integriteta samoregulacijom, detaljno razlaže profesionalna udruženja lobista, njihove stavove prema samoregulaciji i istražuje mnogobrojne opcije za unaprjeđenje transparentnosti i odgovornosti. Naime, samoregulacija lobističkih aktivnosti drugo je lice medalje pa se u izvješću analiziraju mjere koje su poduzele lobističke organizacije s ciljem razvoja pravila ponašanja i pridržavanja zakona i na nacionalnoj i na europskoj razini. Prema istraživanjima, uočen je velik naglasak na povećanju samoregulacije, iako je u tom slučaju izazov osigurati njezino pridržavanje. Zanimljivo je istaknuti kako je čak $61 \%$ intervjuiranih lobista izrazilo želju za uvođenjem obveze regulacije njihovih aktivnosti, dok čak $76 \%$ smatra da bi zakonska regulacija pomogla u otklanjanju negativnog prizvuka povezanog s njihovom profesijom.

\section{ZAKLJUČAK}

Stajalište je međunarodnih organizacija koje djeluju na području Europe kako lobiranje treba biti što transparentnije i otvorenije, a uočena je i sve veća potreba za uspostavom pravnog okvira koji će učinkovito regulirati lobiranje. Bruxelles je centar lobiranja u Europi, a na karti svijeta smješten odmah nakon Washingtona po broju lobista i važnosti u sferi lobiranja. O tome dovoljno govori činjenica da je 2016. godine na lobiranje utrošeno rekordnih 1,7 milijardi eura. Bruxelles se kao takav profilirao tijekom dugog niza godina, a počevši od sredine prošloga stoljeća, izmjenjujući dotičan položaj s Parizom i Ženevom. Kao aktere lobiranja moguće je uočiti šarolik spektar subjekata: od udruga poslodavaca, multinacionalnih kompanija i trgovačkih udruženja preko nevladinih organizacija i udruga pa do predstavnika javnih vlasti. Ne čudi stoga da je u Bruxellesu uočena važnost regulacije lobiranja koja je započela već osamdesetih i devedesetih godina prošloga stoljeća, iako su najvažniji potezi uslijedili u ovom tisućljeću. Tako je 1996. godine Europski parlament uspostavio prvi dobrovoljni registar lobista, dok je Komisija uspostavila „Register of Interest Representatives“ 2008. godine koji se temelji na Europskoj inicijativi za transparentnost (ETI) iz 2005. Godine 2011. uspostavljen je zajednički, objedinjeni registar Europskog parlamenta i Komisije, dok su se 2016. godine pojavile i težnje za uvođenjem zajedničkog, obveznog registra transparentnosti za Parlament, Komisiju i Vijeće.

Za razliku od Bruxellesa, stanje u pojedinim državama članicama Unije vrlo je različito. Litva i Poljska bile su prve koje su donijele zakone o lobiranju, po uzoru na američko zakonodavstvo. U Estoniji lobiranje je obilježeno društvenom stigmom, dok se u Latviji povezuje s djelatnostima poput bankarstva, industrije alkoholnih pića, kockanja i sl.

U Austriji je na snazi zakon koji propisuje obveznost registracije za lobiste te sankcije u slučaju kršenja propisa. Iako je u Češkoj prepoznata važnost regulacije

99 Lobbyists, Government and Public Trust, Volume 2, dostupno na: https://read.oecd-ilibrary.org/ governance/lobbyists-governments-and-public-trust-volume-2_9789264084940-en\#page1, posjećeno 19.1.2018. 
lobiranja, sva su nastojanja dugotrajna i, za sada, bez većeg uspjeha. U Mađarskoj je zakonodavstvo o lobiranju uvedeno još 1994. godine, no tadašnja mađarska vlada opozvala ga je 2011. kao i registar. Registar njemačkog Bundestaga dobrovoljan je i javan, no sve su izraženije tendencije za uvođenjem obveznog registra. U Slovačkoj lobiranje nije regulirano zakonom, dok je slovenski Zakon o regulaciji lobiranja prema nalazima Transparency Internationala najkvalitetniji u Europi. Najnoviji zakon o lobiranju donesen je u Francuskoj 2016. godine, dok su nekoliko godina ranije i Irska (2015.) te Ujedinjeno Kraljevstvo (2014.) uredile pitanje lobiranja zakonskim propisima.

Države Beneluxa odlikuju brojne specifičnosti pa je tako Nizozemska poznata po, tzv. polder modelu i tisućama neregistriranih lobista, a Belgija i Luksemburg nisu donijele zakonodavstvo o lobiranju, niti uspostavile obveznost registracije.

U zemljama južne Europe postoji ozbiljan nedostatak regulacije lobiranja te je sveprisutna negativna konotacija samog pojma, a osobito u državama kao što su Malta, Cipar i Grčka. Italiju karakterizira „,model zmije“ i činjenica da su predložena čak pedeset i četiri zakona o tematici lobiranja, no bez uspjeha. U Portugalu postoje tendencije regulacije lobiranja u budućnosti, kao i u Španjolskoj, bar sudeći prema političkim agendama pojedinih stranaka te uspostavljanju registra transparentnosti u Kataloniji.

U Bugarskoj i Rumunjskoj vidljive su određene naznake napredovanja u pitanju regulacije lobiranja, iako predstoji još mnogo rada do regulacije lobiranja zakonskim tekstom. Iako vrlo profesionalno, lobiranje u Danskoj daleko je od regulacije i točke priznavanja kao zasebne profesije, dok u Finskoj i Švedskoj za sada nema naznaka čvršće regulacije lobiranja.

Vijeće Europe usvojilo je niz preporuka i drugih akata iz područja, tzv. soft law, no u biti se svode na agitiranje za uspostavom iscrpnog pravnog okvira kojim bi se regulirale aktivnosti lobista, dok recentna preporuka iz 2017. godine naglašava i važnost upoznavanja što šire javnosti i što raznolikijih grupa s njenim tekstom, $\mathrm{s}$ ciljem uspostave transparentnosti lobiranja. Istodobno se naglasak stavlja i na nezadiranje u demokratska prava pojedinca kao što su, primjerice, sloboda govora, slanje predstavki i pritužbi i sl. Unatoč tomu, sudska praksa ESLJP-a o lobiranju vrlo je oskudna, odnosno dotiče se tek posredno i marginalno. OECD na lobiranje gleda kroz prizmu suzbijanja korupcije i jačanja integriteta u javnom sektoru. Lobiranje smatra demokratskim pravom građana i interesnih skupina da prezentiraju svoje ideje i interese donositeljima odluka. Istodobno, OECD uočava mnogobrojne probleme s kojima se države suočavaju pri pokušaju regulacije lobiranja te zaključuje kako mnoge od njih odlučuju prepustiti regulaciju samoj profesiji, odnosno kako prevladava samoregulacija.

Što nosi budućnost, teško je anticipirati, no za Europu pa tako i Uniju, turbulentno je razdoblje: od financijske krize, preko migrantske krize pa sve do Brexita. Ipak, jasno je da će u pogledu svakodnevnog, day-to-day businessa, broj lobista u Bruxellesu zasigurno rasti. Velike kompanije nastavit će zapošljavati sve više ljudi, a osobit rast mogao bi uslijediti u industriji koja se galopirajuće razvija - tehnološkoj industriji. Nesumnjiv je rast industrije lobiranja povećanjem broja 
društava koja se bave lobiranjem, kao i rastuća popularnost tečajeva i diplomskih programa koji obuhvaćaju lobiranje ili odnose s javnošću, a uočava se i opći trend profesionalizacije organizacija koje se bave lobiranjem pa se tako unutar industrije donose pravila ponašanja $i$ ističe važnost transparentnosti. Sve su mnogobrojnija i udruženja lobističkih subjekata. Uz tako opisanu generalnu profesionalizaciju lobiranja i donošenje sve većeg skupa internih pravila unutar profesije, uočava se i sve veće pristupanje regulaciji lobiranja u sve više država na području Europe. Osobiti je naglasak na potrebi regulacije prijepornih momenata, kao što su fenomen ,okretnih vrata“, sprječavanje sukoba interesa, financiranje političkih stranaka i sl. Tek ostaje za vidjeti kako će povećanje transparentnosti kroz regulaciju utjecati na poboljšanje percepcije lobiranja, uz naglasak na otvorenost, transparentnost i odgovornost i pravednost, a osobit izazov zasigurno će biti regulacija lobiranja u onim državama u kojima lobiranje nije dio njihove političke kulture.

\section{LITERATURA}

\section{a) Knjige i članci}

1. Bitonti, Alberto, Harris, Phil, Lobbying in Europe, Public Affairs and the Lobbying in 28 EU Countries, Palgrave Macmillan, United Kingdom, 2017.

2. Chalmin, Philippe, The Making of a Sugar Giant: Tate and Lyle 1859-1989, Harwood Academic Publisher, 1990., dostupno na: https://books.google.hr/books?id=bOPogF8v9$\mathrm{kC} \& \mathrm{pg}=\mathrm{PA} 465 \& \mathrm{lpg}=\mathrm{PA} 465 \& \mathrm{dq}=$ henri + cayre + who + was + he $\&$ source $=\mathrm{bl} \&$ ots $=\mathrm{kHi}$ Oh7QRvG\&sig=RDdtcps6n-c86mDU7HPhgYTBsG4\&hl=hr\&sa=X\&ved=0ahUKEwiSj_jFm-XZAhVDICwKHcVHAEoQ6AEIJjAA\#v=onepage \&q=henri\%20cayre $\% 20$ who\%20was\%20he\&f=false, 28. 2. 2018.

3. Chambers, Anthony, The Lobbying of the EU - How to achieve greater transparency, Civitas: Institute for the Study of Civil Society February 2016, dostupno na: http://www. civitas.org.uk/content/files/Anthony-Chambers-EU-lobbying.pdf, 20. 6. 2017.

4. Chari, Raj, Murphy, Gary, Hogan, John, Regulating lobbyists: A comparative analysis of the United States, Canada, Germany, and the European Union, The Political Quarterly 78 (3), 2007.

5. Franklin B. et al., Key concepts in public relations, London: SAGE Los Angeles, 2009, dostupno na: https://books.google.hr/books?hl=hr\&lr= $\mathrm{id}=$ ND1RVZzu8QsC\&oi=fnd\&pg=PT1\&dq=Franklin + B. + et + al., + Key + concepts + in + p ublic+relations, + London: + SAGE + Los + Angeles,$+2009 \&$ ots $=$ HHullIQUqd\&sig=VP2he 6aOs-p3r_bo8vYiyiBZG_I\&redir_esc=y\#v=onepage\&q=consistent\&f=false, 5. 1. 2018.

6. Greenwood, Justin i Thomas, Clive S., Regulating lobbying in the western world, Parliamentary Affairs 51 (4), 1998.

7. Grosek, Kristina, Claros, Eulalia, Regulation of lobbying across the EU, European Parliamentary Research Service, Members' Research Service, dostupno na: http://www. europarl.europa.eu/RegData/etudes/ATAG/2016/595830/EPRS_ATA(2016)595830_ EN.pdf, 21. 6. 2018.

8. Guéguen, Daniel, Europsko lobiranje, Miropictures i Novum, Zagreb, 2007.

9. Holman, Craig, Lobbying Reform in the United States and the European Union: Progress on Two Continents, Public Citizen, 2009.

10. Lobbyists, Government and Public Trust, Vol. 1, dostupno na: https://read.oecd-ilibrary. org/governance/lobbyists-governments-and-public-trust-volume-1_9789264073371en\#page1, 14. 7. 2018. 
11. Lobbyists, Government and Public Trust, Vol. 2, dostupno na: https://read.oecd-ilibrary. org/governance/lobbyists-governments-and-public-trust-volume-2_9789264084940en\#page1, 19. 1. 2018.

12. Lobbyists, Government and Public Trust, Vol. 2, dostupno na: http://www.keepeek.com/ Digital-Asset-Management/oecd/governance/lobbyists-governments-and-public-trustvolume-2 9789264084940-en\#.WmTrsqinHIU, 19. 1. 2018.

13. Petrillo, Pier Luigi, Democrazie sotto pressione, Parlamenti e lobby nel diritto pubblico comparato, Milano, 2011.

14. Vidačak, Igor, Lobiranje, Interesne skupine i kanali utjecaja u Europskoj uniji, Planetopija, Zagreb, 2007.

\section{b) Vrela s Interneta}

1. Access Info Europe: European Commission starts publishing travel expenses proactively, dostupno na: https://www.access-info.org/article/30403, 22. 4. 2018.

2. Algarvedailynews, Former PT directors and Deloitte sued over $€ 897$ million Rioforte loan, https://algarvedailynews.com/news/7647-former-pt-directors-and-deloitte-suedover-897-million-rioforte-loan, posjećeno 30.04.2018.

3. ALTER-EU, The European Transparency Initiative and ALTER-EU, https://www.altereu.org/about/coalitio, 20. 6. 2017.

4. ALTER-EU, Lobbywatch Netherlands Launched, dostupno na: https://www.alter-eu.org/ lobbywatch-netherlands-launched, 10. 7. 2018.

5. ALTER-EU, The French Parliament passes the Sapin II law: a step forward?, dostupno na: https://www.alter-eu.org/the-french-parliament-passes-the-sapin-ii-law-a-step-forward, 10. 7. 2018.

6. Association of Accredited Public Policy Advocates to the European Union, Lobbying Landscape in Hungary, dostupno na: http://www.aalep.eu/lobbying-landscape-hungary, 1.3. 2018.

7. Big East-West skew in record EU lobbying bonanza, Politico, dostupno na: https://www. politico.eu/article/transparency-register-analysis-lobbying-east-west-skew-europeanunion/, 1.3.2018.

8. Civil Society Europe, The European Parliament must do more to improve lobby, transparency, dostupno na: https://civilsocietyeurope.eu/2017/03/17/the-europeanparliament-must-do-more-to-improve-lobby-transparency, 20. 6. 2018.

9. Europa, Registar transparentnosti, dostupno na: http://ec.europa.eu/transparencyregister/ public/homePage.do?redir=false\&locale=hr, 20. 6. 2017.

10. Europa, Registar transparentnosti, Ključni datumi, http://ec.europa.eu/ transparencyregister/public/staticPage/displayStaticPage.do;TRPUBLICID-prod=5 gH3BPKGgTQsiUxtqDzwv7UNnRTcpME-JkTyxS6kKgjNwLqzZet!925169321?locale $=$ hr\&reference=KEY_DATES, 20. 6. 2017.

11. European Commission, Press releases database, Press Release details, Commission's lobby register: it's time to sign up, dostupno na: http://europa.eu/rapid/press-release_IP08-988_hr.htm?locale=en, 20.6. 2018.

12. European Commission - Press release, New Code of Conduct strengthening ethical rules for Members of the European Commission enters into force, Brussels, 31 January 2018 dostupno na: http://europa.eu/rapid/press-release_IP-18-504_en.htm, 26. 2. 2018.

13. Europska komisija - Priopćenje za tisak, Ostvarenje transparentnosti: Komisija predložila obvezni registar transparentnosti za sve institucije EU-a, dostupno na: http://europa.eu/ rapid/press-release_IP-16-3182_hr.htm, 20.6. 2018.

14. Library of Congress, Lobbying Disclosure Laws: France, dostupno na: https://www.loc. gov/law/help/lobbying-disclosure/france.php, 10. 7. 2018. 
15. Library of Congress, Lobbying Disclosure Laws: Germany, dostupno na: https://www. loc.gov/law/help/lobbying-disclosure/germany.php, 1. 7. 2018.

16. Library of Congress, Lobbying Disclosure Laws: United Kingdom, https://www.loc.gov/ law/help/lobbying-disclosure/unitedkingdom.php, 1. 7. 2018.

17. Lobbying.ie, Summary of the main provisions of the Act, dostupno na: https://www. lobbying.ie/help-resources/information-for-lobbyists/quick-guide-to-the-act/, 1. 7. 2018.

18. Lobbying.ie, The Three Step Test, dostupno na: https:/www.lobbying.ie/help-resources/ information-for-lobbyists/am-i-lobbying/, 22. 4. 2018.

19. OECD, Lobbying, dostupno na: http://www.oecd.org/gov/ethics/lobbying.htm, 19. 1. 2018.

20. Politico, Police search offices of Eurogroup President Mário Centeno, https://www. politico.eu/article/police-search-offices-of-eurogroup-president-mario-centeno/, 30. 4. 2018.

21. Politico, Portuguese backlash against plan to remove corruption-busting prosecutor, https://www.politico.eu/article/portuguese-backlash-against-plan-to-remove-corruptionbusting-prosecutor/, 30. 4. 2018.

22. Republic of Slovenia, Government of the Republic of Slovenia, News, Slovenia with the best quality of lobbying regulation in Europe, dostupno na: http://www.vlada.si/en/ media_room/newsletter/slovenia_weekly/news/article/slovenia_with_the_best_quality_ of_lobbying_regulation_in_europe_52774/, 1.7.2018.

23. Reuters, EU executive proposes tighter lobbying rules, 28.rujna 2016,dostupno na: https://www.reuters.com/article/us-eu-ethics-lobbying/eu-executiveproposes-tighter-lobbying-rules-idUSKCN11Y2PW, 28. 2. 2018.

24. Reuters, Portuguese ex-PM Socrates indicted on corruption charges, https://www.reuters. com/article/us-portugal-corruption-socrates/portuguese-ex-pm-socrates-indicted-oncorruption-charges-idUSKBN1CG1U5, 30.04.2018

25. Reuters, Prosecutor investigating suspected fraud at Portugal Telecom SGPS, https:// uk.reuters.com/article/uk-portugaltelecom-investigation/prosecutor-investigatingsuspected-fraud-at-portugal-telecom-sgps-idUKKBN0KF1BG20150106, 30. 4. 2018.

26. Transparency International, Lobbying in Estonia, Mapping the Players, Risks And Political Context, str. 4, dostupno na: http://transparency.ee/cm/files/lisad/lobbying_in estonia.pdf, 11. 3. 2018.

27. Transparency International Slovenia, Lifting the Lid on Lobbying: Slovenia Call for Transparent and Ethical Lobbying, Transparency International Slovenia - Društvo Integriteta, Ljubljana, 2014., dostupno na: http://www.transparency.si/images/publikacije/ lobiranje/report_lobbyinginslovenia.pdf, 1. 7. 2018.

28. Vidačak Igor, Lobiranje u Europskoj uniji, powerpoint prezentacija, http://www.emins. org/pmlr/download/Igor\%20Vidacak_lobiranje-EU.pdf, 20.6.2017.

\section{c) Pravni akti}

1. Francuska, Republika:

- Projet de loi relatif à la transparence, à la lutte contre la corruption et à la modernisation de la vie économique, dostupno na: http://www.assemblee-nationale.fr/14/ta/ta0830.asp, 10. 7. 2017.

2. Hrvatska, Republika:

- Strategija suzbijanja korupcije za razdoblje od 2015. do 2020., NN, br. 26/2015.

- Ustav RH, NN, br. 56/1990., 135/1997., 11/2000., 28/2001., 76/2010. i 5/2014.

3. Irska, Republika

- Transparency of Lobbying, Non-Party Campaigning and Trade Union Administration Act 2014, dostupno na: http://www.legislation.gov.uk/ukpga/2014/4/contents/enacted i http:// www.legislation.gov.uk/ukpga/2014/4/introduction, 1.7.2018. 
4. Komisija, Europska:

- Commission of the European Communities, European Governance, A White Paper, Brussels, 25.7.2001., dostupno na: https://ec.europa.eu/europeaid/sites/devco/files/ communication-white-paper-governance-com2001428-20010725_en.pdf, 5. 1. 2018.

- European Commission: An open structured dialog between the Commission and special interest groups, 1992., 93/C63/02, dostupno na: http://eur-lex.europa.eu/legal-content/ EN/TXT/PDF/?uri=OJ:JOC_1993_063_R_0002_01\&from=EN, 28.2.2018.

- Report from the Commission to the Council and the European Parliament - EU AntiCorruption Report, Brussels, 3.2.2014., dostupno na: https://ec.europa.eu/home-affairs/ sites/homeaffairs/files/e-library/documents/policies/organized-crime-and-humantrafficking/corruption/docs/acr_2014_en.pdf, 10. 7. 2018.

5. Komisija, Venecijanska:

- European Commission for Democracy Through Law (Venice Commission) Report on the Legal Framework for the Regulation of Lobbying in the Council of Europe Member States dostupno na: http://www.venice.coe.int/webforms/documents/default.aspx?pdffile=CDL$\operatorname{DEM}(2011) 002-\mathrm{e}$, 5. 3. 2018.

6. Nizozemska, Kraljevina:

- House of Representatives of the Netherlands - Rules of Procedure, dostupno na: https://www.houseofrepresentatives.nl/sites/default/files/atoms/files/141120-rules_of_ procedure.pdf, 11. 7. 2018.

7. Njemačka, Savezna Republika:

- Anlage 2 der Geschäftsordnung des Deutschen Bundestages - Registrierung von Verbänden und deren Vertretern, dostupno na:

- Bundesgesetz zur Sicherung der Transparenz bei der Wahrnehmung politischer und wirtschaftlicher Interessen (Lobbying- und Interessenvertretungs-Transparenz-Gesetz - LobbyG), dostupno na: Bundeskanzelaramt, https://www.ris.bka.gv.at/Dokument. wxe?Abfrage=Bundesnormen\&Dokumentnummer=NOR40141416, 9. 3. 2018.

- http://www.bundestag.de/parlament/aufgaben/rechtsgrundlagen/go_btg/anlage2/245180, 2. 7. 2018.

8. Organizacija za gospodarsku suradnju i razvitak (OECD):

- 10 Principles for Transparency and Integrity in Lobbying, dostupno na: http://www.oecd. org/gov/ethics/oecdprinciplesfortransparencyandintegrityinlobbying.htm, 18. 1. 2018.

- Recommendation of the Council on Principles for Transparency and Integrity in Lobbying 18 February 2010 - C(2010)16, dostupno na: https://legalinstruments.oecd.org/ Instruments/ShowInstrumentView.aspx?InstrumentID=256\&, 11. 1. 2018.

9. Parlament, Europski:

- European Parliament: A Parliament's Rules of Procedure 9(2), 1996., dostupno na: http://www.europarl.europa.eu/sides/getDoc.do?type=REPORT\&reference=A4-19960200\&language $=\mathrm{EN}, 28.2 .2018$.

- Transparency of lobbying at EU level, Briefing, December 2015, dostupno na: http:// www.europarl.europa.eu/RegData/etudes/BRIE/2015/572803/EPRS_BRI(2015)572803_ EN.pdf, 20. 6. 2017.

10. Slovenija, Republika:

- Zakon o integriteti in preprečevanju korupcije (ZIntPK), Uradni list RS, št. 69/11 - uradno prečiščeno besedilo), dostupno na: http://www.pisrs.si/Pis.web/ pregledPredpisa?id=ZAKO5523, 9. 7. 2018.

11. Unija, Europska:

- Službeni list Europske unije, L 277/11., dostupno na: http://eur-lex.europa.eu/legalcontent/HR/TXT/PDF/?uri=CELEX:32014Q0919(01)\&from=hr, 20. 6. 2017. 
12. Vijeće Europe:

- Recommendation of the Committee of Ministers to member States on the legal regulation of lobbying activities in the context of public decision making (Adopted by the Committee of Ministers on 22 March 2017 at the 1282nd meeting of the Ministers' Deputies), dostupno na: https://rm.coe.int/legal-regulation-of-lobbying-activities/168073ed69, 18. 2. 2017.

- Statute of the Council of Europe, London, 5.V.1949, dostupno na: https://rm.coe. int/1680306052, 1. 3. 2018.

d) Sudska praksa:

1. Europski sud za ljudska prava (ESLJP):

- Dochnal protiv Poljske (br. 31622/07)

- $\quad$ OOO Ivpress i dr. protiv Rusije, (br. 33501/04, 35258/05, 35618/05, 38608/04) 


\section{Sanja Barić* \\ Ana Acinger**}

\section{Summary \\ LEGAL STATUS OF LOBBYISTS IN EUROPE}

The legal regulation of lobbying in Europe is described by the authors through the prism of the European Union, but also of international organizations operating in the territory of Europe and certain countries on its territory. The existence, i.e. nonexistence, of the relevant regulations, of the transparency register and of the code of ethics in the Member States of the European Union, are presented, with special emphasis on those Member States in which there is a legal regulation concerning lobbying and the advantages and disadvantages of such legal acts.

Keywords: European Union, lobbying, right to send petitions and complaints, legal regulation of lobbying, transparency register.

Zussamenfassung

\section{RECHTSREGELUNG DER STELLUNG VON LOBBYISTEN IN EUROPA}

Die Rechtsregelung des Lobbyismus in Europa wird in diesem Beitrag durch das Prisma der EU, der in Europa tätigen völkerrechtlichen Organisationen und einiger europäischer Staaten dargestellt. Ebenfalls wird auch das Vorhandensein, beziehungsweise das Nicht-Vorhandensein einschlägiger Vorschriften, des Transparenzregisters und des ethischen Kodex in den Mitgliedsstaaten der Europäischen Union besprochen. Dabei legt man besonderen Wert auf diejenigen Mitgliedsstaaten, welche über die das Lobbyismus regulierenden Gesetzvorschriften verfügen, und bespricht die Vor- und Nachteile solcher Gesetzesakte.

Schlüsselwörter: die Europäische Union, Lobbyismus, das Recht auf Einreichung von Petitionen und Beschwerden, Rechtsregelung des Lobbyismus, Transparenzregister.

\footnotetext{
* Sanja Barić, Ph.D., Full Professor, University of Rijeka, Faculty of Law; sbaric@pravri.hr.

** Ana Acinger, Legal Trainee at Attorney at Law; ana.acinger@gmail.com.
} 
Riassunto

\section{LA DISCIPLINA GIURIDICA DELLA POSIZIONE DEI LOBBISTI IN EUROPA}

La disciplina giuridica del lobbismo in Europa viene illustrata attraverso il prisma dell'UE, come anche delle organizzazioni internazionali che operano sul territorio dell'Europa e di singoli stati sul suo territorio. Viene illustrata anche l'esistenza, o meglio l'inesistenza, di una disciplina appropriata, di un registro della trasparenza e di un codice etico negli Stati membri dell'Unione europea, con particolare attenzione verso quegli stati membri nei quali non esiste un quadro normativo che regoli il lobbismo, come anche i vantaggi e le lacune di tali atti giuridici.

Parole chiave: Unione europea, lobbismo, diritto all'inoltro di ricorsi e richieste, disciplina giuridica del lobbismo, registro della trasparenza. 
